\title{
Sargasso Sea phosphorus biogeochemistry: an important role for dissolved organic phosphorus (DOP)
}

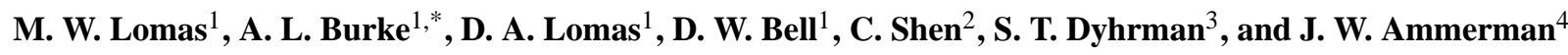 \\ ${ }^{1}$ Bermuda Institute of Ocean Sciences, St. George's GE01, Bermuda \\ ${ }^{2}$ Princeton University, Princeton Environmental Institute, Princeton, New Jersey, 08544, USA \\ ${ }^{3}$ Woods Hole Oceanographic Institution, Biology Department, Woods Hole, Massachusetts, 02543, USA \\ ${ }^{4}$ School of Marine and Atmospheric Sciences, Stony Brook University, Stony Brook, NY 11794-5000, USA \\ * current address: University of Rhode Island, Graduate School of Oceanography, Narragansett, RI 02882, USA
}

Received: 2 October 2009 - Published in Biogeosciences Discuss.: 28 October 2009

Revised: 22 January 2010 - Accepted: 11 February 2010 - Published: 19 February 2010

\begin{abstract}
Inorganic phosphorus (SRP) concentrations in the subtropical North Atlantic are some of the lowest in the global ocean and have been hypothesized to constrain primary production. Based upon data from several transect cruises in this region, it has been hypothesized that dissolved organic phosphorus (DOP) supports a significant fraction of primary production in the subtropical North Atlantic. In this study, a time-series of phosphorus biogeochemistry is presented for the Bermuda Atlantic Time-series Study site, including rates of phosphorus export. Most parameters have a seasonal pattern, although year-over-year variability in the seasonal pattern is substantial, likely due to differences in external forcing. Suspended particulate phosphorus exhibits a seasonal maximum during the spring bloom, despite the absence of a seasonal peak in SRP. However, DOP concentrations are at an annual maximum prior to the winter/spring bloom and decline over the course of the spring bloom while whole community alkaline phosphatase activities are highest. As a result of DOP bioavailability, the growth of particles during the spring bloom occurs in Redfield proportions, though particles exported from the euphotic zone show rapid and significant remineralization of phosphorus within the first $50 \mathrm{~m}$ below the euphotic zone. Based upon DOP data from transect cruises in this region, the southward cross gyral flux of DOP is estimated to support $\sim 25 \%$ of annual primary production and $\sim 100 \%$ of phosphorus export. These estimates are consistent with other research in the subtropical North Atlantic and reinforce the hypothesis that while
\end{abstract}

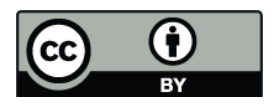

Correspondence to: $\mathrm{M}$. W. Lomas (michael.lomas@bios.edu) the subtropics may be phosphorus stressed (a physiological response to low inorganic phosphorus), utilization of the DOP pool allows production and accumulation of microbial biomass at Redfield proportions.

\section{Introduction}

Phosphorus is a key macronutrient for phytoplankton growth (e.g., DNA, RNA, lipids) and intracellular energy (ATP) and signaling pathways, and as such has the potential to limit oceanic primary production. The traditional paradigm is that marine primary production is nitrogen limited on biologically relevant timescales (Codispoti, 1989; Ryther and Dunston, 1971); however evidence is mounting that suggests oceanic primary production may be limited by inorganic phosphorus (Karl et al., 2001a; Thingstad et al., 2005), such as in the oligotrophic North Atlantic subtropical gyre (Ammerman et al., 2003; Mather et al., 2008). In the subtropical and tropical North Atlantic, SRP concentrations determined using the magnesium co-precipitation method (Karl and Tien, 1992), have been found to be consistently $<10 \mathrm{nmoll}^{-1}$ and often $<1 \mathrm{nmol}^{-1}$ (Cavender-Bares et al., 2001; Wu et al., 2000) in transect cruises through this region. These consistently low inorganic phosphorus concentrations, along with DIN:SRP ratios much greater than the Redfield Ratio, have been used as evidence for inorganic phosphorus stress of primary production in this region. Phosphorus stress is defined in this manuscript as a physiological response to low SRP concentrations, such as the induction of alkaline phosphatase activity, but microbial cells remain able to grow.

Published by Copernicus Publications on behalf of the European Geosciences Union. 
However, phosphorus is also present in a dissolved organic (DOP) pool which often accounts for $>80 \%$ of the total dissolved phosphorus pool in the North Atlantic Ocean (Ammerman et al., 2003; Cavender-Bares et al., 2001; Mahaffey et al., 2004; Vidal et al., 1999; Wu et al., 2000). DOP concentrations in the western tropical and subtropical North Atlantic range from $50-100 \mathrm{nmol}^{-1}$ (Ammerman et al., 2003; Cavender-Bares et al., 2001; Mather et al., 2008; Wu et al., 2000), while in the eastern tropical/subtropical North Atlantic DOP concentrations are much higher, ranging from 100-300 $\mathrm{nmol}^{-1}$ (Mahaffey et al., 2004; Mather et al., 2008; Vidal et al., 1999). The DOP pool is a diverse assemblage of compounds with the largest fraction, on average $\sim 75 \%$ of the DOP amenable to characterization, being esters with much of the remaining fraction being phosphonates (Karl and Bjorkman, 2002; Kolowith et al., 2001; Payan and McLaughlin, 2007). Esters are readily hydrolyzed by bacterial and phytoplankton alkaline phosphatases (Chrost and Overbeck, 1987), and increases in phytoplankton alkaline phosphatase activity have been interpreted as an indicator of inorganic phosphorus stress (e.g., Hoppe, 2003). Indeed, assays for the enzyme alkaline phosphatase (APase) suggest that DOP is readily utilized by the autotrophic community (Dyhrman et al., 2002; Lomas et al., 2004; Mather et al., 2008). Uptake measurements in oligotrophic gyres also indicate that the DOP pool is a potentially important source of P for autotrophs (Benitez-Nelson and Karl, 2002; Bjorkman and Karl, 2003, 2005), particularly in the P-depleted North Atlantic (Casey et al., 2009; Orchard et al., 2010).

Despite the mounting evidence for inorganic phosphorus stress and utilization of DOP in the subtropical North Atlantic, relatively little is known about the seasonal variability in phosphorus biogeochemical parameters. The only seasonal study of high-sensitivity SRP concentrations (using an optimized autoanalyzer with no MAGIC-SRP preconcentration) conducted in the western subtropical North Atlantic at the Bermuda Atlantic Time-series Study (BATS) site (Case, 2001) suggests that there is no seasonal pattern and SRP concentrations approximate the analytical detection limit of $\sim 12 \mathrm{nmol}^{-1}$. Seasonally, euphotic zone $(0-100 \mathrm{~m})$ DOP concentrations at BATS have been shown to decrease from winter through the subsequent fall (Case, 2001). This pattern suggests biological consumption during the spring bloom and into the summer which may explain continued $\mathrm{CO}_{2}$ drawdown during a period of minimum external inorganic nutrient inputs at BATS (Bates, 2001; Michaels et al., 1994b). Salihoglu et al. (2007), using a one-dimensional multi-component lower trophic level ecosystem model that includes detailed algal physiology, showed an increase in euphotic zone DOP concentration at BATS coincident with increased primary production following winter convective mixing, which is consumed during the subsequent summer period. More generally, Salihoglu et al. (2007) observed that the inclusion of an explicit DOP pool, which could be accessed by phytoplankton, significantly improved the fit be- tween modeled and observed carbon fluxes relative to model runs that did not include a DOP pool. This model output implies that DOP may be involved in export production. Using a simplified nutrient cycle and transport model for the eastern North Atlantic, Roussenov et al. (2006) hypothesize northward transport of DOP into the subtropics from the gyral boundaries as part of the surface Ekman wind-driven circulation with 70-80\% of the phosphorus export in the subtropical North Atlantic supported by DOP. Despite the modeled biogeochemical importance of DOP, observational data are sparse and additional datasets are required to evaluate model output and prediction. In this manuscript, we present multiyear records of all the major phosphorus pools at the BATS site and bulk alkaline phosphatase activity (APA) and particulate phosphorus export rates.

\section{Materials and methods}

\subsection{Sample collection}

Samples for phosphorus pool measurements were collected biweekly from February to April and monthly for the remainder of the year at $12-15$ depths in the upper $500 \mathrm{~m}$ (roughly $20 \mathrm{~m}$ intervals in the upper $200 \mathrm{~m}$ and $50 \mathrm{~m}$ intervals from 200-500 m) starting in November 2003 (particulate phosphorus; PPhos), March 2004 (MAGIC-SRP) and June 2004 (total dissolved phosphorus; TDP) and continuing to present. Data through the end of 2008 only are presented in this manuscript. Samples (41) for PPhos analysis were filtered under low pressure $(\sim 50 \mathrm{~mm} \mathrm{Hg})$ onto pre-combusted $\left(450^{\circ} \mathrm{C}, 5 \mathrm{~h}\right) \mathrm{GF} / \mathrm{F}$ filters. Samples were flushed with $\sim 5 \mathrm{ml}$ of $0.17 \mathrm{M} \mathrm{Na}_{2} \mathrm{SO}_{4}$ and stored at $-20^{\circ} \mathrm{C}$ until analysis. Samples for MAGIC-SRP and TDP analysis were collected in acid-cleaned $(10 \% \mathrm{HCl}) 250 \mathrm{ml}$ and $60 \mathrm{ml} \mathrm{HDPE}$ bottles, respectively, from the same Niskin bottle. Both samples were left unfiltered and stored frozen at $-20^{\circ} \mathrm{C}$ until analysis.

Samples for whole-community alkaline phosphatase activity (APA) were collected from 10 depths between 0 $300 \mathrm{~m}$ on monthly cruises from October 2005 to April 2008. Immediately following collection APA assays were conducted. Gravitational phosphorus fluxes were quantified using surface tethered particle interceptor traps (PITs) starting in October 2006 (Knauer et al., 1979). Acrylic tubes $\left(0.0039 \mathrm{~m}^{2}\right.$ cross sectional area) were fitted with acidcleaned $(10 \% \mathrm{HCl})$ polycarbonate membrane filters $(0.8 \mu \mathrm{m})$ at the bottom and then filled with poisoned seawater brine ( $0.7 \%$ formaldehyde, $\sim 50 \mathrm{~g} \mathrm{NaCl}^{-1}$ above ambient seawater salinity). Triplicate tubes were deployed at each of 150,200 , and $300 \mathrm{~m}$ depths for $\sim 72 \mathrm{~h}$ on monthly BATS Core cruises. Following recovery, tubes were allowed to stand for several hours and seawater was siphoned off to the brine/seawater interface. Each tube was then drained through the filter at the bottom of the tube with the filter stored damp 
at $4{ }^{\circ} \mathrm{C}$ and samples of the brine solution stored at $-20{ }^{\circ} \mathrm{C}$ until further processing as described below.

Other hydrographic and biogeochemical measurements have been collected at the BATS site each month since October 1988. Details on sample collection and analysis for these other parameters can be found in the BATS Method Manual (Knap et al., 1997) or online (http://bats.bios.edu/). Access to all the BATS data is through the BATS web page (http://bats.bios.edu/).

\subsection{Sample analysis}

\subsubsection{Particulate phosphorus}

Particulate phosphorus (PPhos) samples were analyzed using the ash-hydrolysis method of Solarzano and Sharp (1980). No efforts were made to separate particulate inorganic from organic phosphorus so data are simply referred to as particulate phosphorus. In addition, there is some evidence that the use of GF/F filters, in comparison with polycarbonate filters of similar pore size, may lead to overestimation of PPhos concentrations, presumably due to adsorption of DOP to the filter (Ammerman, unpubl. Data; 34\% overestimation), although additional testing in our lab found the overestimation to be lower $(\sim 5-10 \%)$ following rinsing with $\mathrm{MgSO}_{4}$ as described here. No corrections were made to PPhos concentrations for this overestimation. For analysis, sample filters were placed in acid-cleaned $(10 \% \mathrm{HCl})$ and pre-combusted glass scintillation vials along with $2 \mathrm{ml}$ of $0.017 \mathrm{M} \mathrm{MgSO}_{4}$, dried down at $80-90^{\circ} \mathrm{C}$ and then combusted at $500^{\circ} \mathrm{C}$ for $2 \mathrm{~h}$. After cooling to room temperature, $5 \mathrm{ml}$ of $0.2 \mathrm{M} \mathrm{HCl}$ was added to each vial and hydrolyzed at $80^{\circ} \mathrm{C}$ for $30 \mathrm{~min}$. After cooling to room temperature, SRP mixed reagent was added (Parsons et al., 1984), sample was clarified by centrifugation, and absorbance read at $885 \mathrm{~nm}$. Sample concentrations were calculated against a potassium monobasic phosphate standard following subtraction of a field blank. The field blank consisted of pre-combusted $\mathrm{GF} / \mathrm{F}$ filters flushed with $\sim 5 \mathrm{ml}$ of $0.17 \mathrm{M} \mathrm{Na}_{2} \mathrm{SO}_{4}$ at sea and then treated identically to the samples. Field blanks were generally $<10 \%$ of the lowest sample concentrations. Oxidation efficiency and standard recovery was tested with each sample run using an ATP standard solution and a certified phosphate standard (Ocean Scientific International Ltd. Phosphate Nutrient Standard Solution). In our laboratory, the precision of this method is $\sim 9 \%$ at $2.5 \mathrm{nmoll}^{-1}$ (the lowest concentrations typically observed well below the euphotic zone), and $\sim 1 \%$ at $15 \mathrm{nmol}^{-1}$ (typical euphotic zone concentrations). The method detection limit, defined herein as three times the standard deviation of the lowest standard $\left(2.5 \mathrm{nmol}^{-1}\right)$ is $\sim 0.1 \mathrm{nmol}^{-1}$.

\subsubsection{Dissolved inorganic phosphate (MAGIC-SRP)}

Dissolved inorganic phosphate (SRP) concentrations in the euphotic zone of the Sargasso Sea are below the analytical detection limits $\left(\sim 20 \mathrm{nmol}^{-1}\right)$ of standard nutrient autoanalyzers. Data presented here were analyzed using the Magnesium Induced Co-precipitation method (Karl and Tien, 1992; Rimmelin and Moutin, 2005) and referred to as MAGIC-SRP in this manuscript. Several modifications to the method are as follows. Sodium hydroxide $(3 \mathrm{M})$ is added to replicate $50 \mathrm{ml}$ samples at a 1:45 vol:vol ratio, samples are shaken and allowed to react for $5 \mathrm{~min}$ shaken again and then centrifuged to form the $\mathrm{Mg}(\mathrm{OH})_{2}$ pellet. The supernatant was decanted and the pellet dissolved in $6 \mathrm{ml}$ of $0.25 \mathrm{M}$ trace metal grade $\mathrm{HCl}$, thus concentrating SRP by 8.3-fold. Arsenate reagent (Johnson, 1971) was added (1:10 vol:vol ratio) to each sample, allowed to react for $15 \mathrm{~min}$ and then the SRP mixed reagent was added to quantify absorbance at $885 \mathrm{~nm}$ (Parsons et al., 1984). It is assumed that following addition of the Arsenate reagent, only SRP remains to react with the color reagents (Karl and Tien, 1997). There is evidence that the MAGIC-SRP method does remove some DOP compounds from solution (whether it be direct scavenging or base hydrolysis of DOP compounds). The potential inclusion of DOP is not accounted for in these calculations and therefore our estimates of MAGIC-SRP concentration may be slight overestimates of actual SRP concentrations. Samples concentrations were calculated against a potassium monobasic phosphate standard, made up in phosphate free seawater following subtraction of an analytical blank, and the accuracy of this standard checked on each run with a certified standard (Ocean Scientific International Ltd. Phosphate Nutrient Standard Solution). With every daily analytical run, aged surface Sargasso Sea water was treated with $\mathrm{NaOH}$ addition as above and the supernatant, now free of SRP, was used to make the analytical blank by adding all reagents as described above. The analytical blank is effectively a reagent blank but includes, to the best of our ability, any matrix effects specific to Sargasso Sea water. The analytical blank had a calculated concentration that was always $<2 \mathrm{nmoll}^{-1}$ standard (lowest used in the standard curve), and generally had a calculated value of $\leq 1 \mathrm{nmoll}^{-1}$. The method detection limit following this protocol is $\sim 1-2$ nmol $^{-1}$ (conservatively defined as $3 \times$ the std dev. of the $2 \mathrm{nmol}^{-1}$ standard, and higher than the calculated reagent blank) with a precision of $\pm 5 \%$ at $5 \mathrm{nmoll}^{-1}$. MAGIC-SRP concentrations compare favorably with BATS autoanalyzer SRP concentrations (MAGIC$\mathrm{SRP}=1.01 \times$ Autoanalyzer $-17.3 \mathrm{nmoll}^{-1}$ ).

\subsubsection{Total dissolved phosphorus and dissolved organic phosphorus}

Total dissolved phosphorus (TDP) concentrations were quantified using the high temperature/acid persulfate oxidation technique as described by Ridal and Moore (1990) with the 
following modifications. Samples and standards, made up in SRP-free seawater, were autoclaved in polypropylene bottles, and following oxidation were concentrated using the MAGIC-SRP method described above to improve method sensitivity. With each batch of samples, standard solutions of glycerophosphate and phosphonic acid were run to monitor overall oxidation efficiency. Analytical blanks for this analysis are complicated by the desire to keep the same seawater matrix between blanks and samples but separate reagent contamination from the large ambient DOP pool. Blank corrections were conducted as follows: P-free seawater was oxidized and concentrated as stated above, with the resulting supernatant (now free of both SRP and DOP) used in making the analytical blank and carried through the entire analytical procedure outlined above. The analytical blank, as for MAGIC-SRP, was the addition of all the reagents for the oxidation and color development added to SRP and DOP free seawater. This reagent blank was subtracted from each sample in the run. Samples were calculated against a potassium monobasic phosphate standard, made up in phosphate free seawater, and the accuracy of this standard checked on each run with a certified standard (Ocean Scientific International Ltd. Phosphate Nutrient Standard Solution). The method detection limit is $10-15 \mathrm{nmoll}^{-1}$, with a precision for the $45 \mathrm{nmoll}^{-1}$ standard of $\pm 4 \%$. Dissolved organic phosphorus (DOP) concentrations are calculated by subtracting MAGICSRP from TDP concentrations.

\subsubsection{Alkaline phosphatase activity}

Whole-community alkaline phosphatase activity (APA) was quantified by following the hydrolysis of the highly sensitive fluorescent substrate 6,8-difluoro-4-methylumbelliferyl phosphate (Invitrogen Inc.), which permits continuous incubation of samples without the need to raise the $\mathrm{pH}$ to maximize fluorescence. The assays were conducted according to the methods of Ammerman (1993), except that a saturating substrate concentration of $10 \mu \mathrm{mol} 1^{-1}$ was used, and therefore the rates presented in this paper are maximal potential hydrolysis rates. All assays were run on $5 \mathrm{ml}$ samples incubated in the dark as a continuous time-course (5-6h total duration) within the linear range of the assay. Samples were read on a Turner Designs TD-700 fluorometer with an Alkaline Phosphatase filter set (Long Wavelength UV Filter Kit; P/N 10-302R). Abiotic substrate hydrolysis was accounted for in killed controls that were boiled and cooled prior to substrate addition. APA rates were calculated from the slope of fluorescent intensity over time after subtracting fluorescence changes in killed controls (Ammerman and Glover, 2000).

\subsubsection{Phosphorus export fluxes}

Samples for particulate phosphorus export (Pflux) were picked free of swimmers following standard BATS protocols (Knap et al., 1997). Samples are examined under both $120 \times$ and $250 \times$ total magnification and all zooplankton removed with fine-tipped forceps. After picking, using a surgical scalpel, all remaining particulate material was scraped into a bolus in the center of the filter. Deionized water was carefully placed on the bolus dropwise to flush away any residual salt, the bolus was dried overnight at $65^{\circ} \mathrm{C}$, and analyzed for phosphorus content as described above for PPhos analyses. No "particulate" blank was measured as there were no particles in the filtered brine solution that could be processed in the same manner as the samples. Sample absorbance was however corrected for the analytical blank which consisted of an empty pre-combusted vial that was taken through the entire analytical procedure described for PPhos determination.

Additionally, starting in August 2007, MAGIC-SRP was measured in the trap brine solution to account for dissolution/remineralization during trap deployment. The same protocol was used as above for MAGIC-SRP, except all standards and brine blanks were made up in the initial poisoned seawater brine. The brine blank, in this analysis, reflects not only reagent but also any contamination in the brine solution, and were subtracted from the samples prior to calculation as described above.

\section{Results}

\subsection{Particulate phosphorus}

PPhos samples have been analyzed from November 2003 to November 2008 representing five annual cycles. A clear seasonal signal is present with maximum PPhos concentrations occurring throughout the euphotic zone at the time of the spring bloom, and minimum annual concentrations generally occurring in the fall period associated with the deep chlorophyll maximum (Figs. 1, 2 and Table 1). Spring PPhos concentrations $\left(16.4 \pm 3.0 \mathrm{nmoll}^{-1}\right)$ were only $(\mathrm{P}=0.003)$ greater than fall PP concentrations $\left(9.1 \pm 1.7 \mathrm{nmol}^{-1}\right)$. Generally, PPhos concentrations ranged from $<5 \mathrm{nmoll}^{-1}$ below the euphotic zone to $\sim 20 \mathrm{nmol}^{-1}$ in the euphotic zone. During the spring in each year, when euphotic zone PPhos was highest, elevated PPhos concentrations were found at depths $>100 \mathrm{~m}$ consistent with the annual peak in PPhos export, and deeper mixed layers resulting in "turbulent drainage" during spring blooms (Backhaus et al., 2003). During the stratified summer period, PPhos concentrations at depths $>100 \mathrm{~m}$ were always $<2 \mathrm{nmoll}^{-1}$, and $<10 \mathrm{nmoll}^{-1}$ within the euphotic zone, consistent with the annual minimum in $\mathrm{P}$ export fluxes and anticipated increases in $\mathrm{P}$ recycling within the upper water column. Integrated euphotic zone PPhos inventories were on average 2- to 3-fold greater than MAGICSRP inventories regardless of the season suggesting a high demand on phosphorus pools to support growth of microbial biomass. 


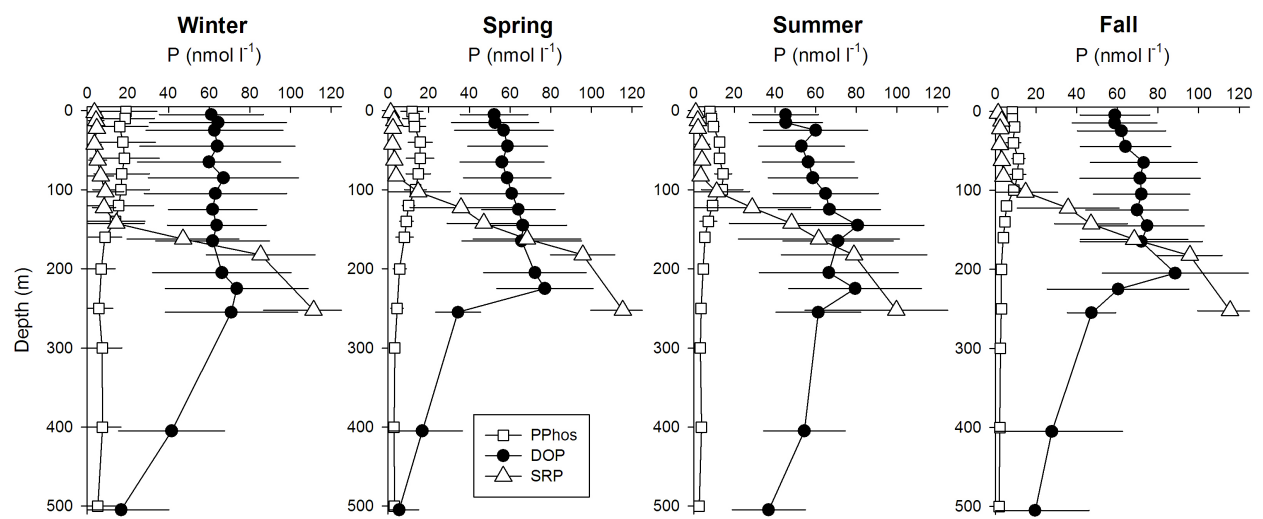

Fig. 1. Seasonal mean (+stdev) profiles of PPhos (squares), DOP (filled circles), and MAGIC-SRP (open triangles) at BATS. All concentrations are in $n$ mol $^{-1} . n=6-15$ for each depth depending upon season and phosphorus pool. Depths are slightly offset such that error bars do not overlap.

Table 1. Seasonal mean (+stdev) euphotic zone phosphorus inventories and rates. Integration depths are given with each parameter. Total $\mathrm{P}$ export is sum of particulate and SRP fluxes. See text for additional details.

\begin{tabular}{|c|c|c|c|c|}
\hline & \multicolumn{4}{|c|}{ Seasonally averaged phosphorus inventories } \\
\hline & Winter (DJF) & Spring (MAM) & Summer (JJA) & Fall (SON) \\
\hline $\operatorname{PPhos}\left(\int 0-100 \mathrm{~m} ; \mathrm{mmol} \mathrm{m}^{-2}\right)$ & $1.8 \pm 1.5$ & $1.4 \pm 0.4$ & $1.3 \pm 0.5$ & $1.0 \pm 0.3$ \\
\hline MAGIC-SRP $\left(\int 0-100 \mathrm{~m} ; \mathrm{mmol} \mathrm{m}^{-2}\right)$ & $0.5 \pm 0.4$ & $0.7 \pm 0.7$ & $0.6 \pm 0.6$ & $0.4 \pm 0.2$ \\
\hline \multirow[t]{3}{*}{$\mathrm{DOP}\left(\int 0-100 \mathrm{~m} ; \mathrm{mmol} \mathrm{m}^{-2}\right)$} & $6.1 \pm 3.5$ & $5.8 \pm 2.0$ & $5.6 \pm 1.9$ & $6.9 \pm 2.2$ \\
\hline & \multicolumn{4}{|c|}{ Seasonally averaged phosphorus rate processes } \\
\hline & Winter (DJF) & Spring (MAM) & Summer (JJA) & Fall $(\mathrm{SON})$ \\
\hline $\operatorname{APA}\left(\int 0-140 \mathrm{~m} ; \mu \mathrm{mol} \mathrm{m}{ }^{-2} \mathrm{~h}^{-1}\right)$ & $248 \pm 121$ & $300 \pm 108$ & $200 \pm 99$ & $190 \pm 55$ \\
\hline${ }^{33} \mathrm{Pi}$ uptake $\left(\int 0-140 \mathrm{~m} ; \mu \mathrm{mol} \mathrm{m}{ }^{-2} \mathrm{~h}^{-1}\right)$ & n.d. & $75.8-141$ & n.d. & 25.4 \\
\hline${ }^{33}$ ATP uptake $\left(\int 0-140 \mathrm{~m} ; \mu \mathrm{mol} \mathrm{m}{ }^{-2} \mathrm{~h}^{-1}\right)$ & n.d. & $4.2-8.6$ & n.d. & 2.8 \\
\hline \multicolumn{5}{|l|}{ Particulate export at $\left(\mu \mathrm{mol} \mathrm{m}{ }^{-2} \mathrm{~d}^{-1}\right)$} \\
\hline $150 \mathrm{~m}$ & $7.6 \pm 7.4$ & $8.2 \pm 3.1$ & $6.9 \pm 3.7$ & $5.8 \pm 2.5$ \\
\hline $200 \mathrm{~m}$ & $4.7 \pm 2.9$ & $5.4 \pm 2.9$ & $4.2 \pm 3.0$ & $2.9 \pm 1.3$ \\
\hline $300 \mathrm{~m}$ & $2.5 \pm 1.4$ & $2.7 \pm 1.2$ & $2.6 \pm 1.5$ & $1.9 \pm 0.9$ \\
\hline \multicolumn{5}{|l|}{ Total $\mathrm{P}$ export $\left(\mu \mathrm{mol} \mathrm{m}{ }^{-2} \mathrm{~d}^{-1}\right)$} \\
\hline $150 \mathrm{~m}$ & $39.2 \pm 19.9$ & $34.0 \pm 22.8$ & $38.8 \pm 5.6$ & $24.0 \pm 9.4$ \\
\hline $200 \mathrm{~m}$ & $41.3 \pm 24.2$ & $25.7 \pm 22.8$ & $24.7 \pm 6.7$ & $25.6 \pm 12.2$ \\
\hline $300 \mathrm{~m}$ & $31.2 \pm 26.6$ & $17.4 \pm 14.9$ & $24.1 \pm 2.6$ & $14.1 \pm 6.9$ \\
\hline
\end{tabular}

\subsection{Dissolved inorganic phosphate (MAGIC-SRP)}

MAGIC-SRP measurements have been made from February 2004 to November 2008. Generally, concentrations were low and uniform over the euphotic zone $(0-100 \mathrm{~m})$ for each season, although occasionally, mean $0-100 \mathrm{~m}$ SRP concentrations exceeded the nominal method detection limit (MDL) for standard autoanalyzer methods $\left(\sim 20 \mathrm{nmoll}^{-1}\right)$ due to particularly high concentrations at $80-100 \mathrm{~m}$ (Fig. 3). No reproducible seasonal cycle in SRP concentration was observed due to significant variability in the annual cycle be- tween years (Fig. 3, Table 1). In 2004 and 2005, there was an increase in SRP (albeit for only 1 cruise) during the spring, with easily detectable concentrations observed throughout much of the euphotic zone, that were then depleted throughout the remainder of the year (Fig. 3). In contrast in 20062008 seasonal patterns in SRP were much less apparent and more variable cruise-to-cruise (Fig. 3).

\subsection{Dissolved organic phosphorus}

Dissolved organic phosphorus (DOP) was the largest measured phosphorus pool in the Sargasso Sea, and was on 


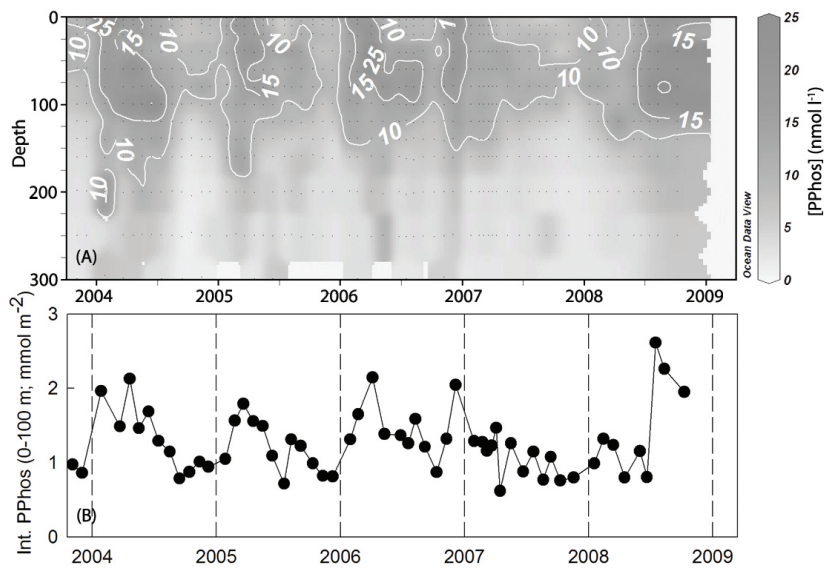

Fig. 2. (A) Time-series contour plot of PPhos concentrations $\left(\mathrm{nmol} \mathrm{l}^{-1}\right)$ in the upper $300 \mathrm{~m}$ of the Sargasso Sea, and (B) timeseries of euphotic zone $(0-100 \mathrm{~m})$ integrated PPhos inventories $\left(\mathrm{mmol} \mathrm{C} \mathrm{m}{ }^{-2} \mathrm{~d}^{-1}\right)$.

average 4- to 7-fold larger than the SRP or PPhos pools (Figs. 1, 4 and Table 1). Due to substantial year-over-year (mid 2004 - late 2007) variability, driven by biological demand for phosphorus, DOP displayed a weak average seasonal pattern with maximum concentrations in winter that slowly decreased through the summer (Fig. 4, Table 1). DOP concentrations were statistically similar throughout the euphotic zone (Fig. 1). In 2005 and 2006 DOP concentrations clearly decreased from winter to summer, but in late 2006 through mid-2007, showed the opposite pattern. These yearover-year patterns were not related to local hydrographic forcing as there were negligible differences in annual minimum and maximum temperatures during this time. Phytoplankton biomass (as Chla) and primary production during the winter/spring of 2007 were $\sim 50 \%$ higher than any other winter/spring period during this study period (Fig. 4b), and consequently so was the likely demand for phosphorus, perhaps resulting in the substantial drawdown of DOP observed during this period (Fig. 4).

\subsection{Whole-community alkaline phosphatase activity}

Whole community alkaline phosphatase activity (APA) was measured from October 2005 to April 2008. Highest potential rates were observed in the euphotic zone, during winter/spring when PPhos and primary production was highest and DOP began to decrease. Indeed, integrated and volumetric APA had a clear seasonal signal with significantly higher values in spring $(P<0.05)$ than summer and fall seasons (Fig. 5, Table 1). Volumetric rates ranged from $0-14 \mathrm{nmol}^{-1} \mathrm{~h}^{-1}$, although most often rates were $<5 \mathrm{nmoll}^{-1} \mathrm{~h}^{-1}$ (Fig. 5). The similarity in seasonal and depth distributions for PPhos and whole-community APA (Pearson Correlation; $r=0.63, \mathrm{P}=0.002$ ) and low activity in the $<0.2 \mu \mathrm{m}$ fraction $(<5 \%$ of the whole community rate)

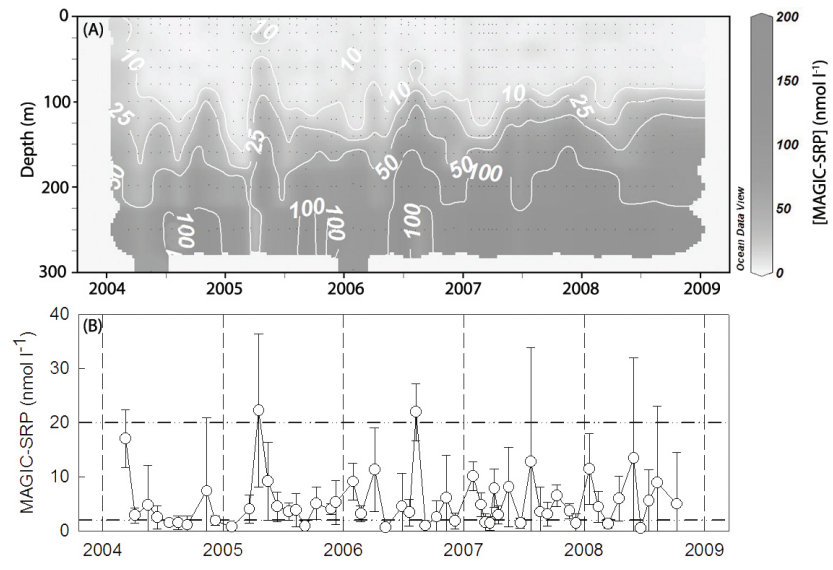

Fig. 3. (A) Time-series contour plot of MAGIC-SRP concentrations $\left.(\mathrm{nmol})^{-1}\right)$ in the upper $300 \mathrm{~m}$ of the Sargasso Sea, and (B) timeseries of euphotic zone (0-100 m) averaged MAGIC-SRP concentrations $\left(\mathrm{nmo}^{-1}\right)$. The dash-dot lines denote the method detection limits (MDL) for standard autoanalyzer methods $\left(\sim 20 \mathrm{nmol}^{-1}\right)$ and our MAGIC-SRP method $\left(\sim 1-2 \mathrm{nmol}^{-1}\right)$.

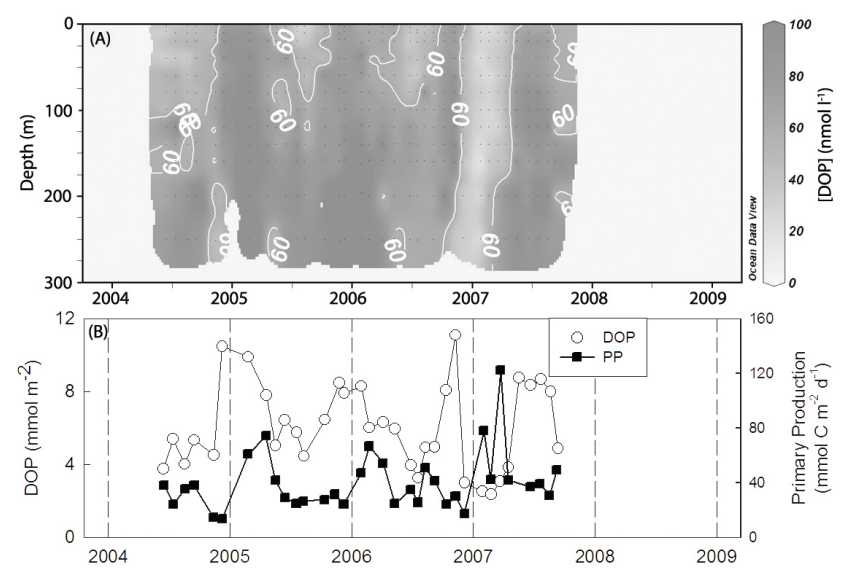

Fig. 4. (A) Time-series contour plot of DOP concentrations $\left(\mathrm{nmol} \mathrm{l}^{-1}\right)$ in the upper $300 \mathrm{~m}$ of the Sargasso Sea, and (B) time-series of euphotic zone $(0-100 \mathrm{~m})$ integrated DOP concentrations $\left(\mathrm{mmol} \mathrm{m}^{-2}\right.$; open circles) and primary production (mmo $\mathrm{C} \mathrm{m}^{-2} \mathrm{~d}^{-1}$; filled squares).

suggests that much of the measured whole-community APA is associated with particles and not free in solution (e.g. Sebastian and Niell, 2004). Furthermore, APA and DOP display similar temporal and vertical patterns (cf. Figs. 4 and 5), although this correlation is not significant (Pearson Correlation; $r=0.35, \mathrm{P}=0.15)$. Highest APA values were found when SRP concentration was $<10 \mathrm{nmoll}^{-1}$ (Fig. 5b).

\subsection{Phosphorus export fluxes}

Particulate phosphorus export fluxes (Pflux) have been measured from October 2005 to November 2008, covering three annual cycles. Particulate phosphorus export has a 


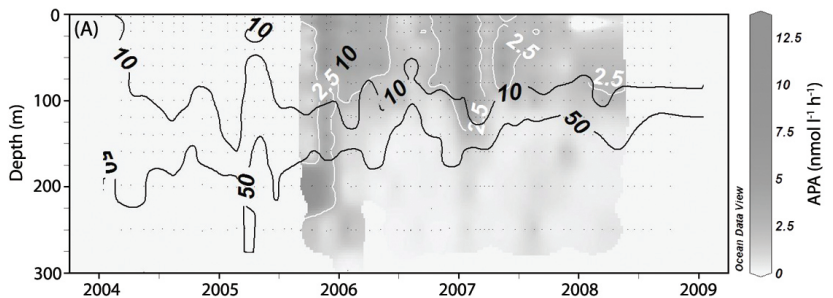

(B)

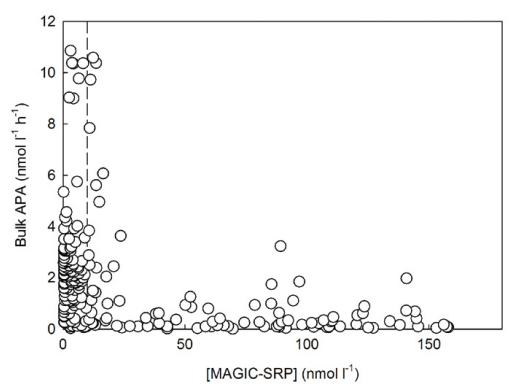

Fig. 5. (A) Time-series contour plot of whole-community alkaline phosphatase activity (APA; $\left.\mathrm{nmol}^{-1} \mathrm{~h}^{-1}\right)$. White lines are the contours for APA, and black lines are contours for SRP concentration. (B) bivariate plot of APA versus ambient SRP concentrations highlighting that the highest APA values are at SRP concentrations $<10 \mathrm{nmoll}^{-1}$ (vertical dashed line).

seasonal pattern with significantly $(\mathrm{P}=0.05)$ higher fluxes at $150 \mathrm{~m}$ in the spring, $8.2 \pm 3.1 \mu \mathrm{mol} \mathrm{m}{ }^{-2} \mathrm{~d}^{-1}$, than the fall, $5.8 \pm 2.5 \mu \mathrm{mol} \mathrm{m}{ }^{-2} \mathrm{~d}^{-1}$ (Fig. 6, Table 1). As with the other parameters, year-over-year variability in seasonal signals was substantial, with Pflux in 2007 and 2008 showing a much weaker/non-existent seasonal signal. Solubilization of phosphorus during the trap deployment was extensive. The flux calculated from the accumulation of SRP in the brine ranged from 70-95\% of the total (sum of Pflux and SRPflux) flux. Although the SRPflux record is too short to comment on year-over-year variability, for the data available no clear seasonal signal is obvious in the total flux (Table 1). Pflux attenuated with depth as expected, with most of the seasonal signal attenuated by $300 \mathrm{~m}$ (Table 1).

\section{Discussion}

\subsection{Seasonality of the Sargasso Sea phosphorus cycle}

The northwestern Sargasso Sea, near the BATS site $\left(31^{\circ}\right.$ $40^{\prime} \mathrm{N}, 64^{\circ} 10^{\prime} \mathrm{W}$ ) is at the southern extent of seasonal atmospheric forcing in the subtropical North Atlantic, and has a seasonal signal with a spring phytoplankton bloom that generally occurs between February and April (e.g., Michaels and Knap, 1996; Steinberg et al., 2001). Seasonality of biogeochemical cycles was first studied in the Sargasso Sea near Bermuda in the 1950's (e.g., Menzel and Ryther, 1960, 1961). However, due to the long entrenched belief that nitro-

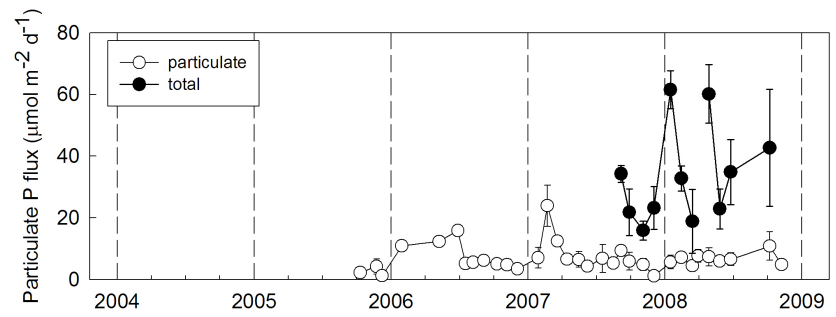

Fig. 6. Time-series of mean $( \pm$ stdev $)$ particulate phosphorus export fluxes at $150 \mathrm{~m}$ (open circles) and the sum of particulate and SRP fluxes (filled circles). See text for description of SRP fluxes. Error bars are stdev of duplicate or triplicate trap tubes.

gen is the primary macronutrient controlling rate processes in the ocean (e.g., Ryther and Dunston, 1971), relatively little attention has been paid to seasonality of the phosphorus cycle in the Sargasso Sea (Michaels et al., 1994a; Michaels et al., 1996). This has only been reinforced by the low SRP concentrations that are difficult to measure.

The phosphorus concentration data collected as part of this study in the western subtropical North Atlantic compare favorably with other studies that have measured various phosphorus pools in the subtropical North Atlantic (Table 2). Case (2001) conducted a seasonal study at the BATS site from 1996-1998. Due to SRP method limitations, $\sim 12 \mathrm{nmol}^{-1}$ method detection limit, no seasonal pattern was observed; however, a seasonal pattern was clearly evident in their PPhos, DOP and APA data records. All three parameters were highest during the winter/spring bloom period: PPhos was highest due to growth and accumulation of phytoplankton, which increased demand on the SRP pool resulting in increased P-stress, the induction of APA and ultimately the hypothesized net consumption of DOP in support of primary production. The present study reinforces and expands upon this interpretation of the seasonal pattern in phosphorus biogeochemistry in the western subtropical North Atlantic. Despite nearly an order of magnitude more sensitive SRP analysis, SRP concentrations remain low and invariant over the seasonal cycle (Fig. 3) and are roughly one third of the euphotic zone integrated PPhos pool which are maximal during the winter/spring bloom (Table 1). Maximum PPhos during the winter/spring bloom, coupled with high net phytoplankton growth rates $\left(0.6-0.9 \mathrm{~d}^{-1}\right.$; Malone et al., 1993) and rapid turnover of the ambient SRP pool (3-5 h; Ammerman et al., 2003) during this same time of year strongly suggest that phytoplankton are relying on the much larger DOP pool for growth. Correlation analysis demonstrates a significant negative relationship between euphotic zone integrated stocks of PPhos and DOP, and no relationship with average euphotic zone temperature (as a proxy for convective mixing of deep water and physical dilution of high DOP surface waters with low DOP deep water) supporting our hypothesis that DOP is consumed in support of the winter/spring bloom 
Table 2. Summary of published phosphorus stock measurements in the subtropical North Atlantic, separated by season. All concentrations are given in nmol $1^{-1}$ and APA in units of nmol $1^{-1} \mathrm{~h}^{-1}$, except where noted in the footnote. Data are given as ranges, means $(+\mathrm{stdev})$ or estimates depending upon how it was presented in the original publication. Eastern subtropical North Atlantic samples are denoted by italics.

\begin{tabular}{llllllll}
\hline Lat/Long & Season & Depth $(\mathrm{m})$ & SRP & PPhos & DOP & APA & Ref. \\
\hline $26-38^{\circ} \mathrm{N}, 65-72^{\circ} \mathrm{W}$ & Spring (Mar) & $\sim 3$ & $0.2-20$ & - & $50-100$ & - & 1 \\
$26-32^{\circ} \mathrm{N}, 64-70^{\circ} \mathrm{W}$ & Spring (Mar) & $\sim 0.5$ & $0.48 \pm 0.27$ & - & $75 \pm 42$ & - & 2 \\
$25-32^{\circ} \mathrm{N}, 58-65^{\circ} \mathrm{W}$ & Spring (Mar) & $\sim 2$ & $10-50$ & - & $90-170$ & $0.3-2.1$ & 3 \\
$20-35^{\circ} \mathrm{N}, 50-64^{\circ} \mathrm{W}$ & Spring (Mar/Apr) & $\sim 10$ & $<1.4-6.3$ & - & $60.2-196.4$ & $2-14$ & 4 \\
$31.7^{\circ} \mathrm{N}, 64.2^{\circ} \mathrm{W}$ & Spring (Mar-May) & $0-100$ & $\sim 15$ & $\sim 15$ & $\sim 75$ & $5-15$ & 5,15 \\
$20-50^{\circ} \mathrm{N}, 20^{\circ} \mathrm{W}$ & Spring (Mar/Apr) & $\sim 3$ & $20-300$ & - & $50-150$ & - & 6 \\
$20-30^{\circ} \mathrm{N}, 20^{\circ} \mathrm{W}$ & Spring (Mar/Apr) & 5 & $<100$ & $\sim 25$ & - & $0-25$ & 7,8 \\
\hline $31-32^{\circ} \mathrm{N}, 59-60^{\circ} \mathrm{W}$ & Summer (Jun) & $\sim 3$ & $10-20$ & - & - & - & 9 \\
$31.7^{\circ} \mathrm{N}, 64.2^{\circ} \mathrm{W}$ & Summer (Jun-Aug) & $0-100$ & $\sim 15$ & $\sim 12$ & $\sim 60$ & $1-5$ & 5,15 \\
$22-50^{\circ} \mathrm{N}, 20-40^{\circ} \mathrm{W}$ & Summer (Jun) & 25 & $<5$ & - & $50-150$ & $0.5-4.5$ & 10 \\
$27-28^{\circ} \mathrm{N}, 13-16^{\circ} \mathrm{W}$ & Summer (Aug) & $0-100$ & $40-530$ & $1-186$ & - & $0.02-0.18$ & 11 \\
\hline $30-31^{\circ} \mathrm{N}, 71-72^{\circ} \mathrm{W}$ & Fall (Nov) & surface & $5-7.5$ & - & - & - & 12 \\
$41^{\circ} \mathrm{N}, 64^{\circ} \mathrm{W}$ & Fall (Sep) & $0-200$ & - & - & $70-100$ & - & 13 \\
$31.7^{\circ} \mathrm{N}, 64.2^{\circ} \mathrm{W}$ & Fall (Sep-Nov) & $0-100$ & $\sim 15$ & $\sim 10$ & $\sim 90$ & $1-3$ & 5,15 \\
$20-30^{\circ} \mathrm{N}, 20^{\circ} \mathrm{W}$ & Fall (Oct/Nov) & $\sim 25$ & $225-425$ & $25-150$ & $100-300$ & $\sim 5$ & 7,8 \\
$22-50^{\circ} \mathrm{N}, 20-40^{\circ} \mathrm{W}$ & Fall (Nov) & 25 & $<5$ & - & $200-325$ & $0.5-1.5$ & 10 \\
$20-25^{\circ} \mathrm{N}, 20-32^{\circ} \mathrm{W}$ & Fall (Sep/Oct) & $\sim 0.5$ & $60 \pm 60$ & - & $200 \pm 50$ & - & 14
\end{tabular}

References: (1) Cavender-Bares et al., 2001; (2) .Wu et al., 2000 - average of all stations, DOP is actually TDP; (3) Sohm and Capone, 2006; (4) Jakuba et al., 2008; (5) Case, 2001 - all data estimated from Fig. 6; (6) Mahaffey et al., 2004; (7) Vidal et al., 1999; (8) Vidal et al., 2003; (9) Li et al., 2008; (10) Mather et al., 2008 - APA in units of nmol $1^{-1} \mathrm{~h}^{-1} \mu \mathrm{gC}-1$; (11) Sebastian et al., 2004 - APA are at tracer level additions; (12) Dyhrman et al., 2002; (13) Ridal and Moore, 1990; (14) Reinthaler et al., 2008; (15) Ammerman et al., 2003.

(Fig. 4, Table 3). This is a pattern that repeats over several years, although year-over-year variability is quite large in this region of the subtropical North Atlantic. This variability could be driven by changes in physical forcing on biological productivity, as well as larger scale changes in the gyre circulation patterns and resultant Ekman nutrient fluxes through the gyres. Transect studies by Jakuba et al. (2008), Mather et al. (2008) and Torres-Valdes et al. (2009), also conducted during the spring period in the western subtropical North Atlantic, reach similar conclusions that DOP is an important phosphorus source supporting phytoplankton production, although those studies base conclusions on DOP concentrations and APA activities alone.

\subsection{Contribution of DOP to primary and export pro- duction in the Sargasso Sea}

A common metric for assessing nutrient stress in phytoplankton is the comparison of measured elemental ratios to the Redfield Ratio (Redfield, 1958); a ratio believed to reflect the balanced elemental composition of marine particles. Arithmetic calculation of elemental POC:PPhos and PON:PPhos ratios of suspended euphotic zone particles in the time-series presented here (2004-2007) are consistent with those reported for 1996-1997 (Ammerman et al., 2003) and average $207 \pm 69$ and $34 \pm 13$, respectively; twice the canonical Red- field Ratios of 106:1 and 16:1 (Table 4). There are no significant seasonal or year-over-year differences in elemental ratios (one-way ANOVA, all pair-wise comparisons $P>0.1$ ), although there is a tendency for POC:PPhos ratios to increase in the summer and fall, which is consistent with increasing Pstress during periods of prolonged stratification. Plotting the same data against each other and calculating the least squares Type II linear regression, which also is the POC:PPhos ratio, one would reach a very different and perhaps more ecologically relevant, conclusion. For the period 2004-2007 the linear regression fit of POC vs. PPhos was 100+8 (Fig. 7, Table 4), statistically identical to the ratio of $\sim 106$ observed a decade earlier (Case, 2001) and the Redfield Ratio of 106:1. Ratios for PON vs. PPhos were $14 \pm 1.4,16.5$ and 16:1 for this study (Fig. 7), Case (2001) and Redfield, respectively. This suggests that as plankton grow and accumulate, much of which occurs during the winter/spring bloom, they do so in Redfield proportions, despite very low SRP concentrations

To better constrain various phosphorus fluxes and quantitatively evaluate the role of DOP in supporting phytoplankton growth and primary production, we construct an approximate flux budget for the BATS region (Fig. 8). For the period 2004-2008, annual primary production at BATS was $13.5 \pm 2.1 \mathrm{~mol} \mathrm{C} \mathrm{m}^{-2} \mathrm{y}^{-1}$. Using the linear regression (Fig. 7) POC:PPhos ratio for particles analyzed during this same period, the estimated annual phosphorus demand is 
Table 3. Correlation matrix of Sargasso Sea euphotic zone $(0-100 \mathrm{~m})$ integrated properties. For each comparison, the top number is the correlation coefficient (with the appropriate sign), the second number is the $\mathrm{P}$-value, significant $(P<0.05)$ correlations are denoted in bold, and the third number is the number of data points in the correlation. Data categories are: DecYr=decimal year; PPhos $=$ particulate $\mathrm{P}$; $\mathrm{DOP}=$ dissolved organic phosphorus; Pflux = particulate $\mathrm{P}$ flux at $150 \mathrm{~m} ; \mathrm{PP}=$ primary production; $T^{\circ} \mathrm{C}=$ temperature averaged over $0-$ $100 \mathrm{~m} ; \mathrm{SRP}=$ soluble reactive phophorus; $\mathrm{APA}=$ alkaline phosphatase activity.

\begin{tabular}{|c|c|c|c|c|c|c|c|}
\hline & PPhos & DOP & Pflux & PP & $T^{\circ} \mathrm{C}$ & SRP & APA \\
\hline \multirow[t]{3}{*}{ DecYr } & -0.32 & 0.22 & -0.49 & -0.50 & 0.76 & -0.18 & 0.10 \\
\hline & 0.02 & 0.20 & $<0.01$ & $<0.01$ & $<0.01$ & 0.20 & 0.65 \\
\hline & 58 & 35 & 31 & 52 & 41 & 55 & 21 \\
\hline \multirow[t]{3}{*}{ PPhos } & & -0.32 & 0.09 & 0.40 & -0.35 & 0.20 & 0.34 \\
\hline & & 0.05 & 0.66 & $<0.01$ & 0.03 & 0.15 & 0.16 \\
\hline & & 35 & 30 & 51 & 41 & 54 & 19 \\
\hline \multirow[t]{3}{*}{ DOP } & & & -0.44 & -0.19 & -0.06 & 0.11 & 0.35 \\
\hline & & & 0.04 & 0.28 & 0.74 & 0.53 & 0.17 \\
\hline & & & 21 & 34 & 31 & 35 & 17 \\
\hline \multirow[t]{3}{*}{ Pflux } & & & & 0.32 & -0.52 & -0.07 & 0.31 \\
\hline & & & & 0.11 & 0.03 & 0.69 & 0.20 \\
\hline & & & & 26 & 17 & 31 & 18 \\
\hline \multirow[t]{3}{*}{ PP } & & & & & -0.53 & 0.26 & -0.17 \\
\hline & & & & & $<0.01$ & 0.07 & 0.48 \\
\hline & & & & & 40 & 48 & 19 \\
\hline \multirow[t]{3}{*}{$T^{\circ} \mathrm{C}$} & & & & & & -0.20 & -0.23 \\
\hline & & & & & & 0.23 & 0.46 \\
\hline & & & & & & 37 & 13 \\
\hline \multirow[t]{3}{*}{ SRP } & & & & & & & -0.23 \\
\hline & & & & & & & 0.31 \\
\hline & & & & & & & 21 \\
\hline
\end{tabular}

$135 \pm 58 \mathrm{mmol} \mathrm{P} \mathrm{m}^{-2} \mathrm{y}^{-1}$. Estimates of vertical SRP input from convection, diapycnal diffusion and eddy upwelling range from 21-31 mmol m $\mathrm{m}^{-2} \mathrm{y}^{-1}$ based upon nitrogen inputs (McGillicuddy et al., 1998) and the measured 100-200 m nitrate:phosphate ratios (Karl et al., 2001b) or modeled inputs (McGillicuddy and Robinson, 1997). Something that has not been considered in previous phosphorus budgets are vertical inputs of DOP. DOP concentrations were measurable between 100-200 m, but there is a decreasing gradient in the profiles, so vertical fluxes should be minimal. Indeed, the decrease in DOP with depths between $200-500 \mathrm{~m}$ may be indicative of net consumption. However, the subtropical mode water, a water mass formed at the surface to the north of BATS and then subducted southward, spans most of this depth range and the low concentrations could be indicative of this different water mass which does have lower DOP when it is formed at the surface (see DOP data in Torres-Valdes et al., 2009). Overall, these results highlight an imbalance in phosphorus demand and vertical supply that is further exacerbated after accounting for export fluxes.

Sediment trap based export fluxes measured in this study comprise two components, what remains as particles and what is solubilized during trap deployment. The importance of solubilization of material captured in sediment traps, and its impact on elemental ratios due to differential solubilization has recently been reviewed (Antia, 2005). Antia (2005) concludes from a range of sediment trap deployments that $70-90 \%$ of total phosphorus flux and $30 \%$ of total organic carbon flux is solubilized during trap deployment. From the current study, the solubilized SRPflux, as a fraction of the total, ranged from $70-95 \%$ (Table 1). Carbon solubilization was not measured, so we used the values given in Antia (2005) to estimate a correction for carbon export fluxes so that elemental ratios can be compared between what is produced in the euphotic zone and what is captured in the traps (Table 1). As calculated for suspended particles, exported material trapped at $150 \mathrm{~m}$ was found to have POC:PPhos and PON:PPhos ratios that are greater than those of the suspended material in the euphotic zone (Table 4). Indeed, the POC:PPhos ratio nearly doubled between the euphotic zone $(0-100 \mathrm{~m})$ average and the $150 \mathrm{~m}$ trap, suggesting that nearly half of the PPhos had already been remineralized before particles were captured in the trap. This additional remineralization was accounted for to better constrain the amount of phosphorus gravitationally settling from the base of the euphotic zone. The phosphorus flux from the euphotic zone was estimated at $23 \mathrm{mmol} \mathrm{m}^{-2} \mathrm{y}^{-1}$ with $12.8 \mathrm{mmol} \mathrm{m}^{-2}$ $\mathrm{y}^{-1}$ exported below $150 \mathrm{~m}$ and the remainder remineralized 
Table 4. Elemental ratios for euphotic zone suspended particles and particles captured in surface tethered traps at the depths noted. Trap particles: corr. are those corrected for solubilization of nutrient elements during trap deployment. See text for additional details.

\begin{tabular}{|c|c|c|}
\hline Parameter & $\begin{array}{l}\text { POC:PPhos } \\
\left(\mathrm{mol} \mathrm{mol}^{-1}\right)\end{array}$ & $\begin{array}{l}\text { PON:PPhos } \\
\left(\mathrm{mol} \mathrm{mol}^{-1}\right)\end{array}$ \\
\hline \multicolumn{3}{|l|}{ Suspended Particles } \\
\hline Arithmetic mean & $207 \pm 69$ & $34 \pm 13$ \\
\hline Linear regression & $100 \pm 8$ & $14 \pm 1.4$ \\
\hline \multicolumn{3}{|l|}{ Trap Particles } \\
\hline \multicolumn{3}{|l|}{ Arithmetic mean } \\
\hline $150 \mathrm{~m}$ & $359 \pm 186$ & $59 \pm 34$ \\
\hline $200 \mathrm{~m}$ & $443 \pm 233$ & $69 \pm 42$ \\
\hline $300 \mathrm{~m}$ & $499 \pm 239$ & $67 \pm 40$ \\
\hline \multicolumn{3}{|l|}{ Linear regression } \\
\hline $150 \mathrm{~m}$ & $255 \pm 57$ & $45 \pm 12$ \\
\hline $200 \mathrm{~m}$ & $216 \pm 66$ & $28 \pm 11$ \\
\hline $300 \mathrm{~m}$ & $364 \pm 105$ & $44 \pm 14$ \\
\hline \multicolumn{3}{|l|}{ Trap Particles: corr. } \\
\hline \multicolumn{3}{|l|}{ Arithmetic mean } \\
\hline $150 \mathrm{~m}$ & $259 \pm 134$ & $48 \pm 27$ \\
\hline $200 \mathrm{~m}$ & $320 \pm 168$ & $57 \pm 34$ \\
\hline $300 \mathrm{~m}$ & $361 \pm 201$ & $55 \pm 33$ \\
\hline \multicolumn{3}{|l|}{ Linear regression } \\
\hline $150 \mathrm{~m}$ & $184 \pm 42$ & $37 \pm 9$ \\
\hline $200 \mathrm{~m}$ & $156 \pm 48$ & $23 \pm 9$ \\
\hline $300 \mathrm{~m}$ & $263 \pm 76$ & $36 \pm 11$ \\
\hline
\end{tabular}

between these two depths, and therefore potentially supporting further euphotic zone phosphorus demand (Fig. 8). While this shallow recycling narrows the imbalance in the phosphorus budget there is still a significant gap between supply and demand.

These observations reinforce the hypothesis that DOP may be a critically important pool supporting primary production in the subtropical North Atlantic (Mather et al., 2008): there are several lines of supporting this hypothesis in the Sargasso Sea. The induction of APA is commonly used as a metric to determine inorganic P-stress and therefore utilization of DOP in support of primary production (e.g., Mather et al., 2008; Sebastian et al., 2004). Using the measured APA results (Fig. 5) and constants derived from kinetic experiments conducted in the Sargasso Sea (Strojsova et al. unpubl. data) in situ euphotic zone APA estimates suggest that DOP hydrolysis would provide $82 \pm 18 \mathrm{mmol} \mathrm{P} \mathrm{m}^{-2} \mathrm{y}^{-1}$ or $\sim 60 \%$ of the estimated annual phosphorus demand. Mather et al. (2008) made the same calculation for the eastern North Atlantic and found that $12-30 \%$ of primary production was supported by DOP. This cross-gyre gradient is consistent with observations of much greater DOP drawdown from east to west (Mather
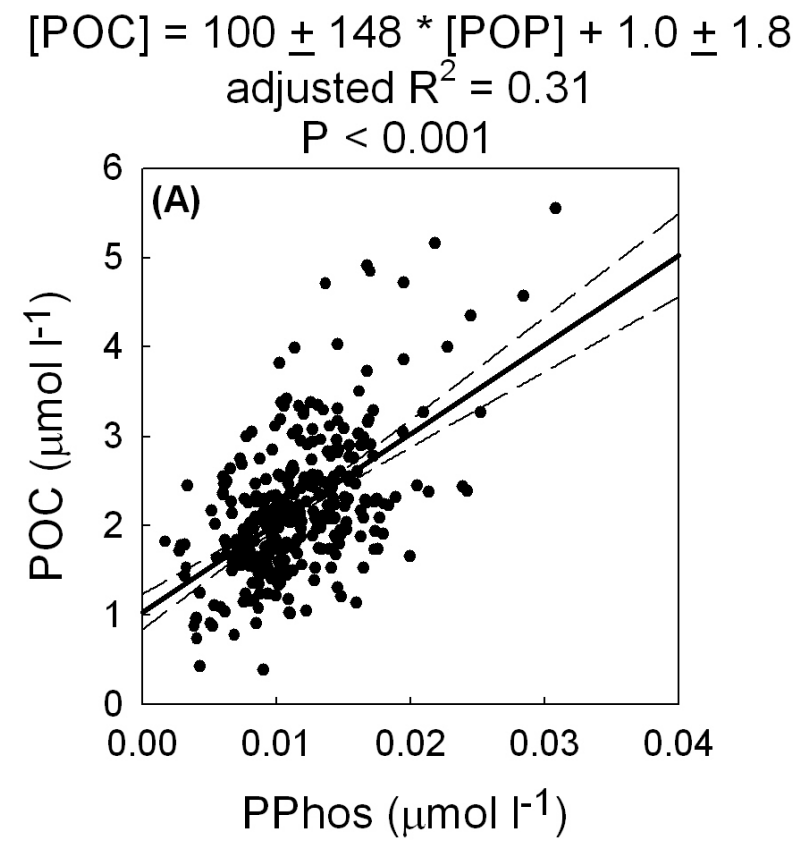
$[P O N]=14.3 \pm 24.4 *[P O P]+0.2 \pm 0.3$ adjusted $R^{2}=0.26$

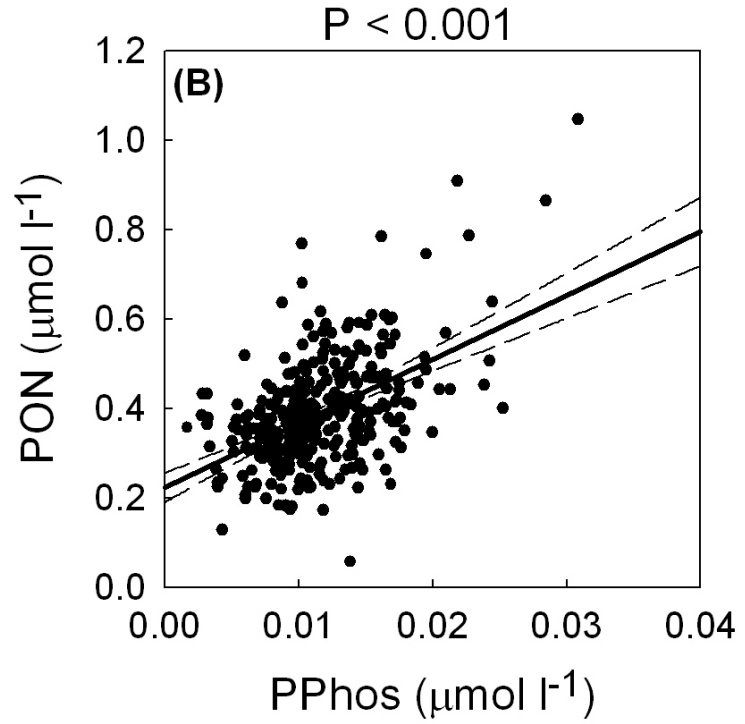

Fig. 7. Bivariate plots of (A) particulate organic carbon POC vs. PPhos and (B) PON vs. PPhos for euphotic zone $(0-100 \mathrm{~m})$ particles during this study period. The solid line in each panel is the least squares linear regression and dashed lines are the $95 \%$ confidence interval. Regression equations ( \pm stdev) are given above each panel.

et al., 2008). Local seasonal drawdown of DOP at BATS is a tiny fraction $(\sim 2 \%)$ of this DOP hydrolysis estimate suggesting a required exogenous source of DOP to the subtropical gyre. Roussenov et al. (2006), based upon data originally presented in Mahaffey et al. (2004) from the eastern subtropical North Atlantic, suggest that throughout the subtropical 


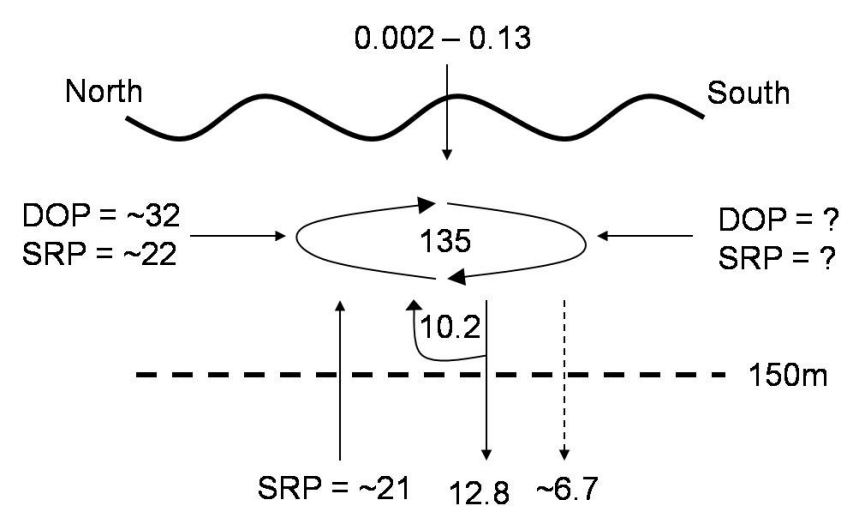

Fig. 8. Phosphorus budget (all fluxes in $\mathrm{mmol} \mathrm{m}^{-2} \mathrm{y}^{-1}$ ) for the BATS region. Dashed export line is the calculated estimate of active zooplankton (including gelatinous zooplankton) export and was not directly measured in this study. See text for details on flux calculations.

North Atlantic there is net production of DOP (and DON; see also Williams and Follows, 1998) in upwelling areas near the gyral boundaries and that some of the DOP produced is ultimately transported into the subtropical gyre via surface Ekman flow from the south where it supports a large component of primary and export production.

We have compiled available DOP transect data for the western subtropical North Atlantic. In contrast to the eastern North Atlantic, there is an increasing gradient from $20-38^{\circ} \mathrm{N}$ (Fig. 8). We do not have data from the equator and $20^{\circ} \mathrm{N}$ where Mahaffey et al. (2004) show a DOP gradient in the eastern North Atlantic to be from the equator to $20^{\circ} \mathrm{N}$. Using the average (1992-2002) Ekman transport from just north of the BATS region $\sim 0.05 \times 10^{6} \mathrm{~m}^{3} \mathrm{~s}^{-1}\left(34^{\circ} \mathrm{N}\right.$, data from Gordon and Giulivi, 2008) and the DOP concentration at $34^{\circ} \mathrm{N}$, $\sim 150 \mu \mathrm{mol} \mathrm{m}^{-3}$ (Fig. 8), we estimate the DOP transport rate into the BATS region (here defined as $34-28^{\circ} \mathrm{N}, 70-60^{\circ} \mathrm{W}$ ) as $\sim 43 \mathrm{mmol} \mathrm{m}^{-2} \mathrm{y}^{-1}$. The precise chemical composition of the DOP pool is unknown and therefore one cannot separate the DOP pool into labile, semi-labile and refractory designations with great confidence. Previous studies (eg., Clark et al., 1999; Kolowith et al., 2001) suggest that roughly $75 \%$ of the DOP pool is comprised of labile esters, with the remainder being "refractory" phosphonates. We assume this to be the case for BATS as well and revise the DOP transport rate downward to $\sim 32 \mathrm{mmol} \mathrm{m}^{-2} \mathrm{y}^{-1}$ to reflect only the labile fraction of advected DOP. It is worth pointing out however that recent research shows that phosphonates may be utilized by autotrophs to support growth (Dyhrman et al., 2006; Ilickchyan et al., 2009; Moore et al., 2005; Palenik et al., 2003), and considering them as refractory may be inaccurate. This southward Ekman flux of estimated labile ester DOP could account for $\sim 25 \%$ of annual phosphorus demand at BATS. A similar calculation for SRP but assuming all SRP is bioavailable (Lomas et al. (2010) SRP concentrations) results in an estimated SRP transport rate of $\sim 22 \mathrm{mmol} \mathrm{m}^{-2} \mathrm{y}^{-1}$. The flux of nutrients (mol time $\mathrm{e}^{-1}$ ) approaches zero with the decrease in Ekman volume flow to $28^{\circ} \mathrm{N}$ (the BATS site is at $31^{\circ} 40^{\prime} \mathrm{N}$ ). It is worth noting that DOP measurements are needed for the western tropical North Atlantic closer to the equator to determine if there is a northward DOP flux as there is in the eastern North Atlantic.

Compiling all of the terms calculated in this section and data from the literature a first order phosphorus annual budget can be completed for the BATS region (Fig. 8). The remaining term is atmospheric deposition. Atmospheric inputs of phosphorus, while perhaps important as singular events, are a minor source of phosphorus to the euphotic zone over the year (Baker et al., 2003; Michaels et al., 1996). While all of the input terms in this budget have large uncertainties, their sum $\left(\sim 85 \mathrm{mmol} \mathrm{P} \mathrm{m}^{-2} \mathrm{y}^{-1}\right)$ roughly balances the biological phosphorus demand of $135 \pm 58 \mathrm{mmol} \mathrm{P} \mathrm{m}^{-2} \mathrm{y}^{-1}$ (Fig. 8). It is worth pointing out that any increase in autotrophic particulate N:P ratio above Redfield (for example if we were to use the arithmetic mean) would serve to bring the demand estimate closer to the supply estimate, thus strengthening this first-order budget. Therefore, we conclude that most of the necessary inputs of phosphorus have been accounted for and that exogenous DOP supports $\sim 25 \%$ of primary production in the western subtropical North Atlantic.

This latter conclusion of an exogenous DOP source is a crucial component in the argument that DOP supports export production; if DOP is recycled locally it can contribute to primary production but not to export production. Based upon modeled estimates of DOP flux between gyres, Roussenov et al. (2006) suggest that between $70-80 \%$ of the phosphorus export in the western subtropical North Atlantic is supported by a labile DOP pool, although one must point out that they have no data for in their model from the western North Atlantic. Using the data presented in this manuscript, the southward Ekman flux of DOP $\left(\sim 32 \mathrm{mmol} \mathrm{P} \mathrm{m}^{-2} \mathrm{y}^{-1}\right)$ is sufficiently large to quantitatively support the observed phosphorus export below $150 \mathrm{~m}\left(\sim 12.8 \mathrm{mmol} \mathrm{P} \mathrm{m}^{-2} \mathrm{y}^{-1}\right)$. Based upon new data in the western Subtropical North Atlantic and a finer-scale model Torres-Valdes et al. (2009) confirm a significant fraction, 60-70\%, of PPhos export production is supported by DOP produced in the eastern North Atlantic and advected to the gyre interior. While the analysis by TorresValdes et al. (2009) focuses on basin scale DOP production and transport, there may be smaller spatial scale production/transport mechanisms as well.

Of concern with this first order mass balance is that there is a significant mismatch between $\mathrm{P}$ inputs to $\left(\sim 85 \mathrm{mmol} \mathrm{P} \mathrm{m}^{-2} \mathrm{y}^{-1}\right)$ and export from $\left(\sim 12.8 \mathrm{mmol} \mathrm{P} \mathrm{m}^{-2} \mathrm{y}^{-1}\right)$ the Sargasso Sea euphotic zone. Having discussed the inputs above, there are several known mechanisms that could result in higher $\mathrm{P}$ export fluxes that were not measured in the PITS traps. First is the active flux mediated by vertically migrating zooplankton. Steinberg et al. (2000) present data on the DIC:DIP ratio 

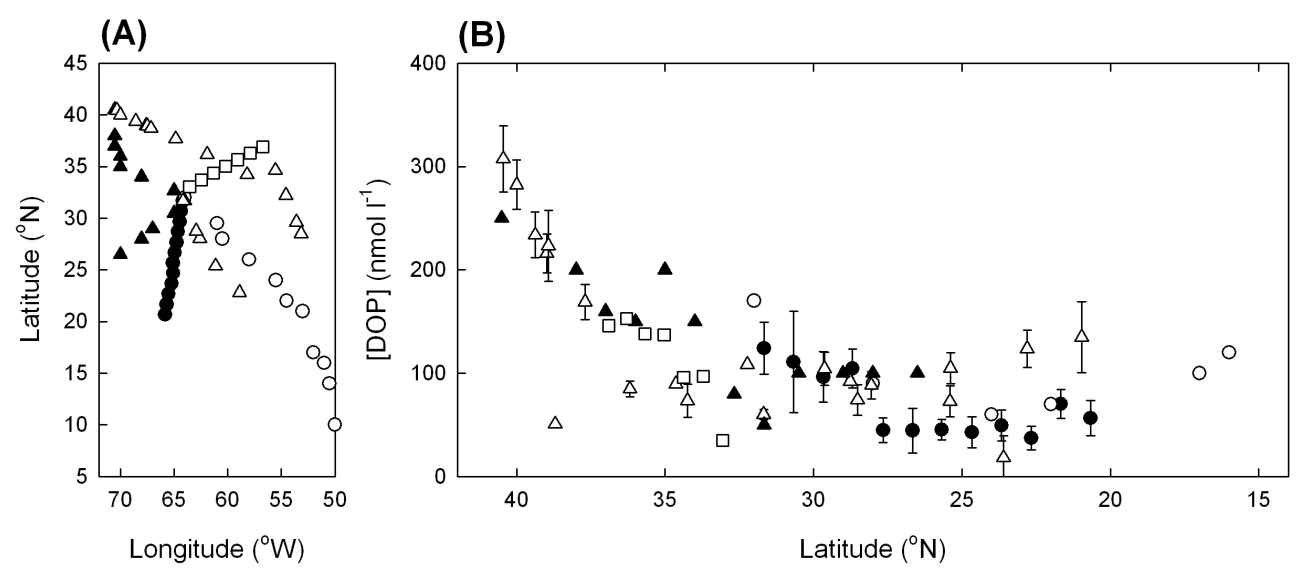

$$
\begin{aligned}
& \text { - Lomas et al. unpubl. - May } 2006 \\
& \text { Sohm and Capone 2006 - March } 2004 \\
& \Delta \quad \text { Jakuba et al. 2008 - March } 2004 \\
& \text { A Cavender-Bares et al. } 2001 \text { - March } 1998 \\
& \square \quad \text { Lomas et al. unpubl. - June } 2007
\end{aligned}
$$

Fig. 9. Compilation of known DOP concentrations $\left(\right.$ nmol $1^{-1}$ ) from transect cruises in the general BATS area. (A) Cruise tracks from which data were collected, and (B) DOP concentrations plotted as a function of latitude. Data were made available by the original author and are identified in the legend.

of excreted material actively transported by crustacean zooplankton and the dissolved carbon (75\% of which is $\mathrm{CO}_{2}$ ) flux. Using this data we estimate a maximum active DIP flux to be $\sim 1.2 \mathrm{mmol} \mathrm{P} \mathrm{m}^{-2} \mathrm{y}^{-1}$. Based upon the work of Hannides et al. (2009) at the Hawaii Ocean Time-series, it is known that vertical migrators can excrete similar concentrations of DIP and DOP at depth. Assuming this is also the case for the North Atlantic; the active grazer flux might be as high as $\sim 2.4 \mathrm{mmol} \mathrm{Pm}^{-2} \mathrm{y}^{-1}$. This is $\sim 20 \%$ of the observed gravitational flux; much less than the contribution of vertical migrators to $\mathrm{P}$ flux in the subtropical North Pacific (avg. $75 \%$ of gravitational flux; Hannides et al., 2009). Steinberg et al. (2001) also suggest that salps may be an important contributor to export flux contributing an additional $\sim 4.3 \mathrm{mmol} \mathrm{P} \mathrm{m}^{-2} \mathrm{y}^{-1}$ (based upon the same assumptions and calculations as used for the crustacean zooplankton). The result is an overall $\sim 50 \%$ increase in export flux (dashed line in Fig. 8); significant but still not sufficient to balance inputs and outputs. Another possible explanation for the discrepancy is a bias in the PITS traps collection efficiency due to hydrodynamic shear. Work by Stanley et al. (2004) shows that, with respect to P fluxes, neutrally buoyant sediment traps (not effected by shear) and PITS traps yield statistically identical P fluxes over two seasons (June and September) and two depths $(150 \mathrm{~m}$ and $300 \mathrm{~m}$ ). Thus any bias due to export flux trap design might be relatively small for $\mathrm{P}$ in the subtropical North Atlantic. It appears there is a missing export term that requires further investigation.

\subsection{Long term changes in $P$ cycling.}

Two phosphorus time-series records exist at BATS, this study and that of Case (2001), and they provide a unique assessment of the role of DOP in the western subtropical North Atlantic over the past decade. It is important to note that these two studies used different methods for quantifying DOP; Case (2001) used the ash hydrolysis method of Solorzano and Sharp (1980), while the current study used the high temperature acid persulfate method. These two methods were continually checked for quantitative oxidative efficiency at the time the samples were analyzed. In addition, these two methods have been compared previously (e.g., Monaghan and Ruttenberg, 1999) and found, for all but two of the DOP compounds tested, to yield statistically similar oxidation efficiencies. So while concentrations changes over time may be due to methodological differences it seems more likely that it is a real decrease in DOP.

Mean DOP concentrations in this study were 30-50\% lower than measured a decade earlier at BATS (Case, 2001), and similar to recent transects in the western subtropical North Atlantic near BATS (Mather et al., 2008). The microbial community in the western subtropical North Atlantic readily assimilates DOP (e.g., Casey et al., 2009; Dyhrman et al., 2002; Lomas et al., 2004; Orchard et al., 2010) and a large fraction of the total phosphorus export is believed to be supported by DOP, therefore it is plausible that over the past decade DOP concentrations may have been slowly drawn down via the biological pump. If this process is indeed occurring, then there should be some evidence for it in permanent thermocline waters; here defined 


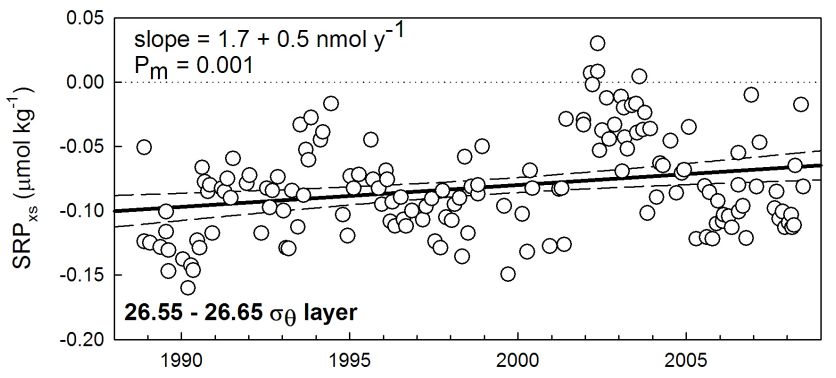

Fig. 10. $\mathrm{SRP}_{x s}$ data (calculated as $\mathrm{SRP}_{x s}=\mathrm{SRP}-\mathrm{NO}_{3} / 16$ ) in permanent thermocline waters at BATS. Data are from the $\sigma_{\theta}=26.55$ $25.65 \mathrm{~kg} \mathrm{~m}^{-3}$, which is centered around $500 \mathrm{~m}$.

as $\sigma_{\theta}=26.55-26.65$ which is approximately $500 \mathrm{~m}$ depth. Based upon the quasi-conservative biogeochemical tracer $\mathrm{SRP}_{x s}$ (cf. Bates and Hansell, 2004), $\mathrm{SRP}_{x s}$ concentrations (all derived from BATS core program data using consistent methodology) have increased significantly $(\mathrm{P}=0.001)$ from 1989 through 2008 at a rate of $1.7 \pm 0.5 \mathrm{nmol} \mathrm{kg}^{-1} \mathrm{y}^{-1}$ (Fig. 10). Over the decade between the two datasets discussed, this would account for the accumulation of $\sim 17 \mathrm{nmol}$ $\mathrm{kg}^{-1} \mathrm{SRP}$, or roughly the difference in euphotic zone DOP concentrations between this study and that of Case (2001). This increase in $\mathrm{SRP}_{x s}$ over the past 2 decades would also bring euphotic zone DOP concentrations in the western subtropical North Atlantic right in line with current DOP concentrations in the eastern subtropical North Atlantic which are hypothesized to be higher due to lower total phosphorus demand (Mather et al., 2008) and/or higher SRP inputs and greater recycling (Cianca et al., 2007; Helmke et al., 2010). More importantly, permanent thermocline waters appear to be returning to Redfield stoichiometry $\left(\mathrm{SRP}_{x s}=0\right)$ from an SRP depleted state hypothetically driven by nitrogen fixation (e.g., Michaels et al., 2001). We are only beginning to understand these multi-year to decadal changes in elemental stoichiometry in the ocean and the controls exerted on these ratios by the amazing diversity of ocean biota (Karl et al., 2001a).

\section{Summary}

Taken together, the data presented in this manuscript suggest that even if the Sargasso Sea near BATS is inorganic phosphorus stressed, this stress has not, as yet, negatively impacted microbial biomass and rate processes, perhaps it has even allowed for an increase in rate processes given that primary production has doubled from 1997 to present, (Lomas et al., 2010). Maintaining this microbial activity has placed a heavy biological demand on the DOP pool resulting in its decrease over the past decade. The data presented here support the hypothesis first proposed by Roussenov et al. (2006) for the eastern subtropical North Atlantic, that pro- ductivity in the subtropical North Atlantic is fueled in part by the exogenous supply of DOP from the tropical and subpolar gyres. However, we cannot completely rule out changes in atmospheric phosphorus inputs supporting primary production due a lack of temporal data (Tian et al., 2008). Based upon the data in this manuscript, we suggest that forecasting models of ocean productivity should consider not only changes in vertical mixing and atmospheric inputs, but also cross gyral organic nutrient inputs to the subtropics which dominate global productivity (e.g., Behrenfeld et al., 2006).

Acknowledgements. We thank all the project technicians past and present who have assisted in the collection of the samples presented in this manuscript. We thank the anonymous reviewers whose comments have improved this manuscript. This research was supported by the NSF Biological Oceanography Program through awards OCE-0453023 (MWL), OCE-0451419 (STD), OCE-0452904 (JWA). We also acknowledge support for the Bermuda Atlantic Time-series Study provided by the NSF Chemical and Biological Oceanography Programs through the most recent awards OCE 0326885 and OCE 0752366. CS thanks The Charrock Foundation and Princeton Environmental Institute for her support. This is Bermuda Institute of Ocean Sciences Contribution 1721.

Edited by: C. P. Slomp

\section{References}

Ammerman, J. W.: Microbial cycling of inorganic and organic phosphorus in the water column, in: Handbook of Methods in Aquatic Microbial Ecology, edited by: Kemp, P., Sherr, B. F., Sherr, E. B., and Cole, J., Lewis Publishers, Boca Raton, 649660, 1993.

Ammerman, J. W. and Glover, W.: Continuous underway measurments of microbial ectoenzyme activities in aquatic ecosystems, Marine Ecology Progress Series, 201, 1-12, 2000.

Ammerman, J. W., Hood, R. R., Case, D., and Cotner, J. B.: Phosphorus deficiency in the Atlantic: an emerging paradigm in oceanography, EOS, 84, 165-170, 2003.

Antia, A. N.: Solubilization of particles in sediment traps: revising the stoichiometry of mixed layer export, Biogeosciences, 2, 189204, 2005, http://www.biogeosciences.net/2/189/2005/.

Backhaus, J., Hegseth, E., Wehde, H., Irigoien, X., Hatten, K., and Logemann, K.: Convection and primary production in winter, Mar. Ecol. Prog. Ser., 251, 1-14, 2003.

Baker, A., Kelly, S., Biswas, K., Witt, M., and Jickells, T.: Atmospheric deposition of nutrients to the Atlantic Ocean, Geophys. Res. Lett., 30, doi:10.1029/2003GL018518, 012003, 2003.

Bates, N. and Hansell, D.: Temporal variability of excess nitrate in the subtropical mode water of the North Atlantic Ocean, Mar. Chem., 84, 225-241, 2004.

Bates, N. R.: Interannual variability of oceanic $\mathrm{CO}_{2}$ and biogeochemical properties in the Western North Atlantic subtropical gyre, Deep-Sea Res. Part II, 48, 1507-1528, 2001.

Behrenfeld, M., O’Malley, R., Siegel, D., McClain, C., Sarmiento, J., Feldman, G., Milligan, A. J., Falkowski, P., Letelier, R. M., and Boss, E.: Climate-driven trends in contempary ocean productivity, Nature, 444, 752-755, 2006. 
Benitez-Nelson, C. and Karl, D.: Phosphorus cycling in the North Pacific Subtropical Gyre using cosmogenic 32P and 33P, Limnol. Oceanogr., 47, 762-770, 2002.

Bjorkman, K. and Karl, D. M.: Bioavailability of dissolved organic phosphorus in the euphotic zone at station ALOHA, North Pacific subtropical gyre, Limnol. Oceanogr., 48, 1049-1057, 2003.

Bjorkman, K. M. and Karl, D. M.: Presence of dissolved nucleotides in the North Pacific Subtropical Gyre and their role in cycling of dissolved organic phosphorus, Aquat. Microb. Ecol., 39, 193-203, 2005.

Case, D.: The Inventory, Seasonality and Stoichiometry of the Major Phosphorus Pools in the Sargasso Sea, Oceanography, 52 pp., 2001.

Casey, J., Lomas, M., Michelou, V., Dyhrman, S., Orchard, E., Ammerman, J., and Sylvan, J.: Phytoplankton taxon-specific orthophosphate $(\mathrm{Pi})$ and ATP utilization in the western subtropical North Atlantic, Aquat. Microb. Ecol., 58, 31-44, 2009.

Cavender-Bares, K. K., Karl, D. M., and Chisholm, S. W.: Nutrient gradients in the western North Atlantic Ocean: relationship to microbial community structure and comparison to patterns in the Pacific Ocean, Deep-Sea Res. I, 48, 2373-2395, 2001.

Chrost, R. J. and Overbeck, J.: Kinetics of alkaline phosphaase activity and phosphorus availability for phytoplankton and bacterioplankton in Lake Plussee (North-German eutrophic lake), Micro. Ecol., 13, 229-248, 1987.

Cianca, A., Helmke, P., Mourino, B., Rueda, M. J., Llinás, O., and Neuer, S.: Decadal analysis of hydrography and in situ nutrient budgets in the western and eastern North Atlantic subtropical gyre, J. Geophys. Res., 112, C07025, doi:10.1029/2006JC003788, 2007.

Clark, L. L., Ingall, E. D., and Benner, R.: Marine organic phosphorus cycling: novel insights from nuclear magnetic resonance, Am. J. Sci., 2999, 724-737, 1999.

Codispoti, L.: Phosphorus vs. Nitrogen limitation of new and export production, in: Productivity of the Ocean: Present and Past, edited by: Berger, W., Smetacek, V., and Wefer, G., John Wiley \& Sons, Chichester, UK, 377-394, 1989.

Dyhrman, S. T., Chappell, P. D., Haley, S. T., Moffett, J. W., Orchard, E. D., Waterbury, J., and Webb, E. A.: Phosphonate utilization by the globally important marine diazotroph Trichodesmium., Nature, 439, 68-71, 2006.

Dyhrman, S. T., Webb, E. A., Anderson, D. M., Moffett, J. W., and Waterbury, J. B.: Cell-specific detection of phosphorus stress in Trichodesmium from the Western North Atlantic, Limnol. Oceanogr., 47, 1832-1836, 2002.

Gordon, A. and Giulivi, C.: Sea surface salinity trends over fifty years within the subtropical North Atlantic, Oceanography, 21, 20-29, 2008.

Hannides, C., Landry, M. L., Benitez-Nelson, C., R, Styles, R., Montoya, J., and Karl, D. A.: Export stoichiometry and migrantmediated flux of phosphorus in the North Pacific Subtropical Gyre, Deep Sea Res. I, 56, 73-88, 2009.

Helmke, P., Neuer, S., Lomas, M., Conte, M., and Freudenthal, T.: Cross-basin differences in particulate organic carbon export and flux attenuation in the subtropical North Atlantic Gyre, Deep Sea Res. I, 57, 213-227, 2010.

Hoppe, H. G.: Phosphatase activity in the sea, Hydrobiologia, 493, 187-200, 2003.

Ilickchyan, I., McKay, R., Zehr, J., Dyhrman, S., and Bullerjahn,
G.: Detection and expression of the phosphonate transporter gene phnD in marine and freshwater picocyanobacteria, Environ. Microbiol., 11, 1314-1324, 2009.

Jakuba, R., Moffett, J. W., and Dyhrman, S. T.: Evidence for the linked biogeochemical cycling of zinc, cobalt, and phosphorus in the western North Atlantic Ocean, Global Biogeochem. Cy., 22, GB4012, doi:10.1029/2007GB003119, 2008.

Johnson, D.: Simultaneous determination of arsenate and phosphate in natural waters, Environ. Sci. Technol., 5, 411-414, 1971

Karl, D., Bjorkman, K., Dore, J., Fujieki, L., Hebel, D., Houlihan, T., Letelier, R., and Tupas, L.: Ecological nitrogen to phosphorus stoichiometry at station ALOHA, Deep-Sea Res. II, 48, 15291566, 2001a

Karl, D., Dore, J., Lukas, R., Michaels, A., Bates, N., and Knap, A.: Building the long-term picture: The U.S. JGOFS Time-series programs, Oceanography, 14, 6-17, $2001 \mathrm{~b}$.

Karl, D. M. and Bjorkman, K.: Dynamics of DOP, in: Biogeochemistry of Marine Dissolved Organic Matter, edited by: Hansell, D. and Carlson, C. A., Academic Press, New York, USA, 250-366, 2002.

Karl, D. M. and Tien, G.: MAGIC: A sensitive and precise method for measuring dissolved phosphorus in aquatic environments, Limnol. Oceanogr., 37, 105-116, 1992.

Karl, D. M. and Tien, G.: Temporal variability in dissolved phosphorus concentrations in the subtropical North Pacific ocean, Mar. Chem., 56, 77-96, 1997.

Knap, A., Michaels, A., Steinberg, D., Bahr, F., Bates, N., Bell, S., Countway, P., Close, A., Doyle, A., Howse, F., Gundersen, K., Johnson, R., Little, R., Orcutt, K., Parsons, R., Rathbun, C., Sanderson, M., and Stone, S.: BATS Methods Manual Version 4 , 1997.

Knauer, G., Martin, J., and Bruland, K.: Fluxes of particulate carbon, nitrogen, and phosphorus in the upper water column of the northeast Pacific, Deep-Sea Res., 26, 97-108, 1979.

Kolowith, L., Ingall, E., and Benner, R.: Composition and cycling of marine organic phosphorus, Limnol. Oceanogr., 46, 309-320, 2001.

Li, Q., Hansell, D. A., and Zhang, J.: Underway monitoring of nanomolar nitrate plus nitrite and phosphate in oligotrophic seawater, Limnol. Oceanogr., 6, 319-326, 2008.

Lomas, M. W., Swain, A., Shelton, R., and Ammerman, J. W.: Taxonomic variability of phosphorus stress in Sargasso Sea phytoplankton, Limnol. Oceanogr., 49, 2303-2310, 2004

Lomas, M. W., Steinberg, D. K., Dickey, T., Carlson, C. A., Nelson, N. B., Condon, R. H., and Bates, N. R.: Increased ocean carbon export in the Sargasso Sea linked to climate variability is countered by its enhanced mesopelagic attenuation, Biogeosciences, 7, 57-70, 2010, http://www.biogeosciences.net/7/57/2010/.

Mahaffey, C., Williams, R., Wolff, G., and Anderson, W. Physical supply of nitrogen to phytoplankton in the Altantic Ocean, Global Biogeochem. Cy., 18, GB1034, doi:1010.1029/2003GB002129, 2004.

Malone, T., Pike, S., and Conley, D.: Transient variations in phytoplankton productivity at the JGOFS Bermuda Time-series Station, Deep-Sea Res. Part I, 40, 903-924, 1993.

Mather, R., Reynolds, S., Wolff, G., Williams, R. G., Torres-Valdes, S., Woodward, E. M. S., Landolfi, A., Pan, X., Sanders, R. W., and Achterberg, E.: Phosphorus cycling in the North and South Atlantic Ocean subtropical gyres, Nature Geosci., 1, 439-443, 
2008.

McGillicuddy, D. and Robinson, A.: Eddy-induced nutrient supply and new production in the Sargasso Sea, Deep-Sea Res. II, 44, 1427-1450, 1997.

McGillicuddy, D., Robinson, A., Siegel, D., Jannasch, H., Johnson, R., Dickey, T., McNeil, J., Michaels, A., and Knap, A.: Influence of mesoscale eddies on new production in the Sargasso Sea, Nature, 394, 263-266, 1998.

Menzel, D. W. and Ryther, J. H.: The annual cycle of primary production in the Sargasso Sea off Bermuda, Deep-Sea Res., 6, 351367, 1960.

Menzel, D. W. and Ryther, J. H.: Annual variations in primary production of the Sargasso Sea off Bermuda, Deep Sea Res., 7, 282288, 1961

Michaels, A., Karl, D., and Capone, D.: Element stoichiometry, new production and nitrogen fixation, Oceanography, 14, 68-77, 2001.

Michaels, A. and Knap, A.: Overview of the U.S. JGOFS Bermuda Atlantic Time-series Study and the Hydrostation S program, Deep-Sea Res. II, 43, 157-198, 1996.

Michaels, A., Knap, A., Dow, R., Gundersen, J., Johnson, R., Sorensen, J., Close, A., Knauer, G., Lohrenz, S., Asper, V., Tuel, M., and Bidigare, R.: Seasonal patterns of ocean biogeochemistry at the U.S. JGOFS Bermuda Atlantic Time-series study site, Deep-Sea Res., 41, 1013-1038, 1994a.

Michaels, A. F., Bates, N. R., Buesseler, K. O., Carlson, C. A., and Knap, A. H.: Carbon-Cycle Imbalances in the Sargasso Sea, Nature, 372, 537-540, 1994b.

Michaels, A. F., Olson, D., Sarmiento, J. L., Ammerman, J. W., Fanning, K., Jahnke, R., Knap, A. H., Lipschultz, F., and Prospero, J. M.: Inputs, losses and transformations of nitrogen and phosphorus in the pelagic North Atlantic Ocean, Biogeochemistry, 35, 181-226, 1996.

Monaghan, E. and Ruttenberg, K.: Dissolved organic phosphorus in the coastal ocean: Reassessment of available methods and seasonal phosphorus profiles from the Eel River Shelf, Limnol. Oceanogr., 44, 1702-1714, 1999.

Moore, L. R., Ostrowski, M., Scanlan, D. J., Feren, K., and Sweetsir, T.: Ecotypic variation in phosphorus acquisition mechanisms within marine picocyanobacteria, Aquat. Microb. Ecol., 39, 257269,2005

Orchard, E. D., Ammerman, J. W., Lomas, M. W., and Dyhrman, S. T.: Dissolved inorganic and organic phosphorus uptake in the Sargasso Sea: variability in Trichodesmium and the microbial community, Limnol. Oceanogr., 55, in press, 2010.

Palenik, B., Brahamsha, B., Larimer, F. W., Land, M., Hauser, L., Chain, P., Lamerdin, J., Regala, W., Allen, E. E., McCarren, J., Paulsen, I., Dufresne, A., Partensky, F., Webb, E. A., and Waterbury, J.: The genome of a motile marine Synechococcus, Nature, 424, 1037-1042, 2003.

Payan, P. and McLaughlin, K.: The oceanic phosphorus cycle, Chem. Rev., 107, 563-576, 2007.

Redfield, A.: The biological control of chemical factors in the environment, American Scientist, 46, 205-221, 1958.

Reinthaler, T., Sintes, E., and Herndl, G.: Dissolved organic matter and bacterial production and respiration in the sea-surface microlayer of the open Atlantic and the western Mediterranean Sea, Limnol. Oceanogr., 53, 122-136, 2008.

Ridal, J. and Moore, R.: A re-examnation of the measuremnt of dissolved organic phosphorus in seawater, Mar. Chem., 29, 1931, 1990.

Rimmelin, P. and Moutin, T.: Re-examination of the MAGIC method to determine low orthophosphate concentration in seawater, Anal. Chim. Acta, 548, 174-182, 2005.

Roussenov, V., Williams, R. G., Mahaffey, C., and Wolff, G.: Does the transport of dissolved organic nutrients affect export production in the Atlantic Ocean?, Global Biogeochem. Cy., 20, GB3002, doi:3010.1029/2005GB002510, 2006.

Ryther, J. and Dunston, W.: Nitrogen, phosphorus and eutrophication in the coastal marine environment, Science, 1008-1013, 1971.

Salihoglu, B., Garcon, V., Oschlies, A., and Lomas, M.: Influence of nutrient utilization and remineralization stoichiometry on phytolankton species and carbon export: a modeling study at BATS., Deep Sea Res. I, 2007.

Sebastian, M., Aristequi, J., Montero, M., Escanez, J., and Niell, F. X.: Alkaline phosphatase activity and its relationship to inorganic phosphorus in the transition zone of the North-western African upwelling system, Prog. Ocean., 62, 131-150, 2004.

Sebastian, M. and Niell, F.: Alkaline phosphatase activity in marine oligotrophic environments: implications of single-substrate addition assays for potential activity estimations, Marine Ecol. Prog. Ser., 277, 285-290, 2004.

Sohm, J. and Capone, D. G.: Phosphorus dynamics of the tropical and subtropical north Atlantic: Trichodesmium spp. versus bulk plankton, Marine Ecol. Progress Series, 317, 21-28, 2006.

Solorzano, L. and Sharp, J. H.: Determination of total dissolved phosphorus and particulate phosphorus in natural waters, Limnol. Oceanogr., 25, 754-758, 1980.

Stanley, R. H. R., Buesseler, K. O., Manganini, S. J., Steinberg, D. K., and Valdes, J. R.: A comparison of major and minor elemental fluxes collected in neutrally buoyant and surface-tethered sediment traps, Deep-Sea Res. I, 51, 1387-1395, 2004.

Steinberg, D. K., Carlson, C. A., Bates, N. R., Goldthwait, S. A., Madin, L. P., and Michaels, A. F.: Zooplankton vertical migration and the active transport of dissolved organic and inorganic carbon in the Sargasso Sea, Deep-Sea Res. I, 47, 137-158, 2000.

Steinberg, D. K., Carlson, C. A., Bates, N. R., Johnson, R. J., Michaels, A. F., and Knap, A. H.: Overview of the US JGOFS Bermuda Atlantic Time-series Study (BATS): a decade-scale look at ocean biology and biogeochemistry, Deep-Sea Res. II, 48, 1405-1447, 2001.

Thingstad, T., Krom, M., Mantoura, R., Flaten, G., Groom, S., Huerut, B., Kress, N., Law, C., Pasternak, A., Pitta, P., Psarra, S., Rassoulzadegan, R., Tanaka, T., Tselepides, A., Wassmann, P., Woodward, E., Wexels Riser, C., Zodiatis, G. and Zohary, T.: Nature of phosphorus limitation in the ultraoligotrophic eastern mediterranean, Science, 309, 1068-1071, 2005.

Tian, Z., Ollivier, P., Veron, A., and Church, T.: Atmospheric $\mathrm{Fe}$ deposition modes at Bermuda and the adjacent Sargasso sea, Geochem. Geophys. Geosyst., 9, Q08007, doi:10.1029/2007GC001868, 2008.

Torres-Valdes, S., Rousseau, V., Sanders, R. W., Reynolds, S., Pan, X., Mather, R., Landolfi, A., Wolff, G., Achterberg, E., and Williams, R.: Distribution of dissolved organic nutrients and their effect on export production over the Atlantic Ocean, Global Biogeochem. Cy., 23, GB4019, doi:4010.1029/2008GB003389, 2009. 
Vidal, M., Duarte, C., Agusti, S., Gasol, J., and Vaque, D.: Alkaline phosphatase activities in the central Atlantic Ocean indicate large areas with phosphorus deficiency, Marine Ecol. Prog. Ser., 262, 43-53, 2003.

Vidal, M., Duarte, C. M., and Agusti, S.: Dissolved organic nitrogen and phosphorus pools and fluxes in the central Atlantic Ocean, Limnol. Oceanogr., 44, 106-115, 1999.
Williams, R. and Follows, M.: The Ekman transfer of nutrients and maintenance of new production over the Atlantic Ocean, Deep Sea Res. I, 45, 461-489, 1998.

Wu, J., Sunda, W., Boyle, E., and Karl, D.: Phosphate depletion in the western North Atlantic Ocean, Science, 289, 759-762, 2000. 